\title{
THE LUPA ROMANA IN THE ROMAN PROVINCES
}

\author{
MIKA RISSANEN \\ University of Jyväskylä, Department of Languages (Latin) \\ 40014 Jyväskylä, Finland \\ E-mail: mika.rissanen@hotmail.it
}

\begin{abstract}
The she-wolf with the twins, Romulus and Remus, was identified as a symbol of Rome by both the Romans themselves and nations under the Roman rule. In this essay I will discuss the Lupa Romana in Roman provincial art. I will present various visual representations of the she-wolf both in the public use and in objects related to private life, and analyze the she-wolf's symbolic meaning.

The Lupa Romana was an iconic scene that was not used randomly in provincial art. It represented in the first place the idea of romanitas, being Roman. In some cases the use of the symbol could have been in consequence of instructions from Rome itself or from provincial authorities that depended on Rome, but in most cases the motif was used by the inhabitants of the provinces themselves. It can be seen as an expression of loyalty to Rome and the emperor, but at the same time the message could have been directed to other members of the community, too. As romanitas was associated with higher social status, the she-wolf motif in the decoration of one's house or gravestone could be seen as self-aggrandizement.

Keywords: lupa Romana, Roman iconography, Roman provincial archaeology, Roman provincial art, romanitas, Romanisation
\end{abstract}

The she-wolf with the twins Romulus and Remus has served as a symbol of Rome for more than two millennia. In Antiquity, Rome was identified with the Lupa Romana in both literature and the visual arts. The she-wolf represented not only the city that was founded by her foster children but also the whole Roman Empire and romanitas, the idea of being Roman. This identification was made not only by the Romans themselves but by other nations too; both enemies of Rome and nations under Roman rule were aware of the lupine connection.

In this essay I will discuss the Lupa Romana in Roman provincial art. ${ }^{1}$ I will present various visual representations of the she-wolf and analyze the she-wolf's symbolic meaning, especially in the provincial context. The symbol appears both in public use (such as on coins, on imperial cuirasses and in architectural decoration) and in objects related to private life (such as on personal belongings and gravestones). I will also look into some details which have not previously been studied very thoroughly, such as the geographical distribution of the artifacts that have been preserved and the restrictions that might have been placed on the use of the she-wolf image.

${ }^{1}$ The iconography of the Lupa Romana has previously been analyzed e.g. in DuliÈRE 1979; WeIGEL 1992, 292-296; PARISI PresicCe 2000; and Dardenay 2012. 


\section{BACKGROUND: THE SHE-WOLF IN ROME}

The history of the relationship between Rome and the wolf goes back to the very beginning of the new city. The myth of the she-wolf that suckled Romulus and Remus was known at least from the beginning of the $4^{\text {th }}$ century $\mathrm{BCE},{ }^{2}$ possibly already in the first half of the $6^{\text {th }}$ century BCE. ${ }^{3}$ Wolves also had a major religious role in the early Roman cult of the Lupercalia. ${ }^{4}$ Even though the dating of the famous bronze sculpture Lupa Capitolina ${ }^{5}$ and the identification of the persons in the so-called Mirror of Bolsena ${ }^{6}$ are disputed, I am inclined to regard them as the two oldest surviving visual representations of the birth myth of Rome. In the development of the she-wolf motif, the most important milestone is the silver didrachm minted in $269 \mathrm{BCE}$ (Fig. 1). ${ }^{7}$ The position of the animal (standing in a trapezoidal composition, with its neck turned three quarters to face the twins, who are on their knees beneath her), became the archetype of the Lupa Romana and was repeated for centuries, the she-wolf facing either right, as on this coin, or left. The double nature of the she-wolf is clear: she is both a loving foster mother (characterized by her teats and her attention focused on the infants), and a ferocious beast, as shown in her predator's jaw and her shaggy mane. ${ }^{8}$

The first representations of the she-wolf myth were directed to the Romans themselves, but as the republic grew larger and came to include many different peoples and nations, some common symbolism was needed to create unity. ${ }^{9}$ The Lupa Romana fitted the bill perfectly. It was not an official - or the only - symbol of Rome, but it was more distinctive than other commonly used icons, the goddess Roma or the eagle, which was used on the standards of the Roman legions.

The she-wolf and the twins were used as an identifying symbol in visual representations of the River Tiber ${ }^{10}$ and the goddess Roma. ${ }^{11}$ The Lupa Romana symbolized Rome also without the twins, as can be seen on a denarius minted by Publius Satrienus in $77 \mathrm{BCE},{ }^{12}$ and on coins minted by the Samnites during the Civil War of

${ }^{2}$ T. J. CoRnell: La leggenda della nascita di Roma. In: Carandini-CAPpelli 2000, 45-50; K. A. RaAflaub: Romulus und die Wölfin. Roms Anfänge zwischen Mythos und Geschichte. In: E. Stein-Hölkeskamp - K.-J. Hölkeskamp (Hrsg.): Erinnerungsorte der Antike. München 2006, 23.

${ }^{3}$ J. N. BREMMER: Romulus, Remus and the foundation of Rome. In: J. N. Bremmer - N. Horsfall: Roman Myth and Mythography. London 1987, 47-48; A. CARANDINI: Introduzione. In: CARANDINI 2006, xxi; A. Rodriguez Mayorgas: Romulus, Aeneas and the cultural memory of the Roman Republic. Athenaeum 98 (2010) 93-94.

${ }^{4}$ On the Lupercalia, see e.g. A. W. J. Holleman: Pope Gelasius I and the Lupercalia. Amsterdam 1974; A. ZIOLKOWSKI: Ritual cleaning-up of the city: from the Lupercalia to the Argei. AncSoc 29 (1999) 191-218; P. CARAFA: Appendice III: I Lupercali. In: CARANDINI 2006, 477-493.

${ }^{5}$ A. M. Carruba (Lupa Capitolina. Un bronzo medievale. Roma 2006) suggested a medieval dating instead of the traditional dating to the early $5^{\text {th }}$ century BCE. The discussion is continued in BARTOLONi 2010; M. R.-Alföldi - E. Formigli - J. Fried: Die römische Wölfin. Ein antikes Monument stürzt von seinem Sockel / The Lupa Romana. An antique monument falls from her pedestal. Stuttgart 2011; and C. PARISI PRESICCE: La Lupa di Roma. Roma 2011, 26-30.

${ }^{6}$ T. P. WISEMAN (The she-wolf mirror: an interpretation. Papers of the British School at Rome 61 [1993] 1-7) suggests that the mirror, dating from 340-330 BCE, has nothing to do with the legend of the origin of Rome, because the she-wolf on the mirror is not suckling Romulus and Remus but the Lares. He is supported by F. C. Albertson (Mars and Rhea Silvia in Roman Art. Collection Latomus 336. Bruxelles 2012, 22-24). This view is contested by A. CARAndini (Sullo specchio con lupa, Romolo e Remo (di nuovo a proposito di T. P. Wiseman). Ostraka 6 [1997] 445-446), for example. On other interpretations of the mirror, see R. CAPPELLI: Il Luper- cale più antico e più affollato: lo specchio di Bolsena. In: CARANDINI - CAPPElli 2000, 233-234; N. CANU: Le valenze del lupo nel mondo Romano. Periodo arcaico ed età repubblicana. Università Degli Studi di Sassari (diss.) 2005, 153-163; C. MAzzoni: She-Wolf. The Story of a Roman Icon. New York 2010, 174-178; DARDENAY 2010a, 35-39. DuLIÈRE (1979, II, F1) regards the mirror as a forgery, but presents no arguments to support her theory. Her view is widely contested.

${ }^{7}$ Crawford 1972, 20. Cf. Plin. nat. 33, 44: Argentum signatum anno urbis CCCCLXXXV, Q. Ogulnio C. Fabio cos. "Silver was not impressed with a mark until the year of the City 485 , the year of the consulship of Q. Ogulnius and C. Fabius" (translated by J. Bostock). The image on the coin possibly depicts the statue erected near the Lupercal in 296 BCE, mentioned by Livy $(10,23,12)$ : Eodem anno Cn. et $Q$. Ogulnii aediles curules ( - - ) ad ficum Ruminalem simulacra infantium conditorum urbis sub uberibus lupae posuerunt" [This year] the curule aediles, Gnaeus and Quintus Ogulnius ( - - ) placed near the Ficus Ruminalis a group representing the Founders of the City as infants being suckled by the she-wolf" (translated by C. Roberts). Cf. DULIÈRE 1979, I, 58-62; DARDENAY 2010a, 52-55. On the contrary, J. Evans $(1992,59-63)$ suggests the dating of the $2^{\text {nd }}$ century BCE.

${ }^{8}$ Cf. Mazzoni 2010, 169-186; L. Cracco Ruggini: L'opinione di uno storico. In: BARTOLONI 2010, 111-115.

${ }^{9}$ E. STRong: Sulle tracce della Lupa Romana. In: R. Paribeni, et al. [ed.]: Scritti in onore di Bartolomeo Nogara : raccolti in occasione del suo LXX anno. Città del Vaticano 1937, 482.

${ }^{10}$ Dulière 1979, II, 31-34; AichHolzer 1983, Kat.176 and 184-185; PARISI PRESICCE 2000, 28.

${ }^{11}$ DuLIÈRE 1979, II, 28-30.

${ }^{12}$ Crawford $(1972,388)$ suggests that the reason for the appearance of the "predatory" wolf without twins could possibly be a counter-reaction to the coins minted by Italian rebels. 

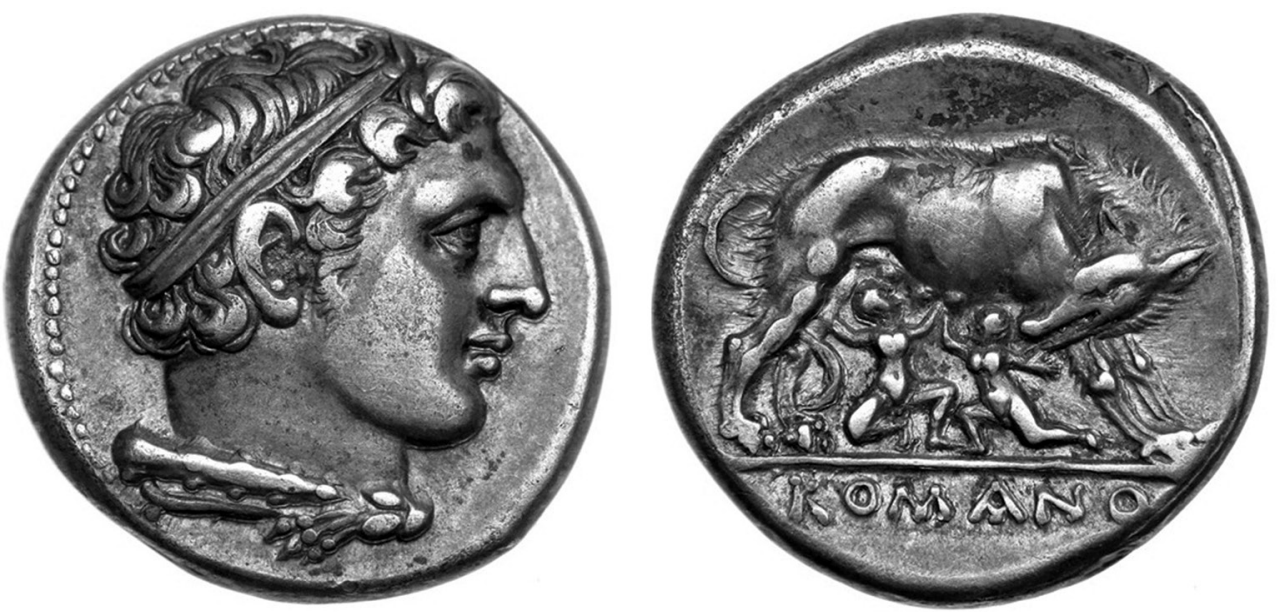

Fig. 1. Roman silver didrachm, minted in 269 BCE. Obverse: Head of Hercules.

Reverse: She-wolf suckling Romulus and Remus, with the text ROMANO. Photo source: www.icollector.com

90-89 BCE. ${ }^{13}$ In literature the Romans were sometimes allegorically described as wolves, usually in a martial context. ${ }^{14}$

In the Augustan Age, the Lupa Romana became an essential element that was used in various ways in imperial propaganda. ${ }^{15}$ In the first place, the miraculous survival of Romulus and Remus with the help of an animal sacred to Mars was interpreted as a sign of the divine protection afforded to Rome. Secondly, the she-wolf motif served as a symbol of fertility and abundance, proclaiming the beginning of aurea aetas, the new Golden Age. Thirdly, Augustus wanted to present himself as a new Romulus, founder of the new Rome, and this association was supported by the use of the she-wolf motif in public decoration. ${ }^{16}$ The images preserved from the Augustan Age have been found mainly near Rome, ${ }^{17}$ but in the second half of the first century CE the she-wolf motif became widely known in the Roman provinces, too.

\section{ROMAN COINAGE}

The first widespread minting of coins with the she-wolf motif was introduced by the Emperor Vespasian and his sons Titus and Domitian in 71-79 CE. Their coins of different values (aureus, denarius, sestertius) were minted in Rome, and have been found in many provinces of the Empire. On the obverse there is an image of the emperor, on the reverse the she-wolf with the twins (or alternatively, with the goddess Roma). ${ }^{18}$ The representation of the she-wolf on coins did not change much over the centuries. ${ }^{19}$ The pictorial motif used on imperial coins was chiefly adopted from the $3^{\text {rd }}$ century BCE silver didrachm presented above (Fig. 1). The coins were minted in abundance in the $2^{\text {nd }}$ and $3^{\text {rd }}$ centuries CE, especially during the reigns of Hadrian, Antoninus Pius and Philippus

${ }^{13}$ A. Campana: La monetazione degli insorti italici durante la Guerra sociale (91-87 a.C.). Modena 1987, 85-89; F. TATARANNI: Il toro, la lupa e ilguerrero: L'immagine marziale de isanniti nella monetazione degli insorti italici durante la guerra sociale (90-88 a.C.). Athenaeum 93 (2005) 293-300.

${ }^{14}$ E.g. Liv. 3,66,3-4; Hor. carm. 4,4,49-53;Vell. 2,27,2.

15 Weigel 1977, 25; Evans 1992, 71-72; PARISI PresicCe 2000, 19-25; AMisAno 2004, 1-17. DuliÈre (1979, I, 144-146) suggests that one reason for the decline in the popularity of the Romulus and Remus motif in the $1^{\text {st }}$ century BCE could be that the fratricide committed by Romulus could have taken on an invidious association with the Roman civil wars.
${ }^{16}$ P. Zanker: Augustus und die Macht der Bilder. München 1987, 206-209; Evans 1992, 91-102; PARISI PresicCe 2000, 25.

${ }^{17}$ The she-wolf with Romulus and Remus appears e.g. in the Ara Pacis and in the pediment of the Temple of Mars Gradivus (outside the Porta Capena). Evans 1992, 69-70.

${ }^{18}$ H. Mattingly-E. A. Sydenham (eds.): Roman Imperial Coinage (=RIC) II, n. 66, 70, 194, 204, 241, 442; DULIÈRE 1979, I, 154-155; II, 80-81, M18-M21; AICHHOLZER 1983, Kat. 257-262; C. FERRO:'Immagini della memoria'. Romolo nei tipi monetali di età imperiale. Scienze dell'Antichità 16 (2010) 227-229; DARDENAY 2012, 257 n. L40-L42.

${ }^{19}$ Parisi Presicce 2000, 30; Weigel 1977, 25. 
Arabs. ${ }^{20}$ In the $4^{\text {th }}$ century, Constantine the Great favored the image of the goddess Roma on the obverse of his shewolf coins. ${ }^{21}$ These coins of Constantine, as will be shown below, became a model for some of the coins and artwork produced in Anglo-Saxon Britain.

On Roman coins the she-wolf represented both the above-mentioned divine protection afforded to Romulus and Remus - and consequently, to the Roman Empire - and the idea of aeternitas, the eternity of Rome (see Fig. 2), which was proclaimed as a part of imperial propaganda from the time of Augustus. ${ }^{22}$

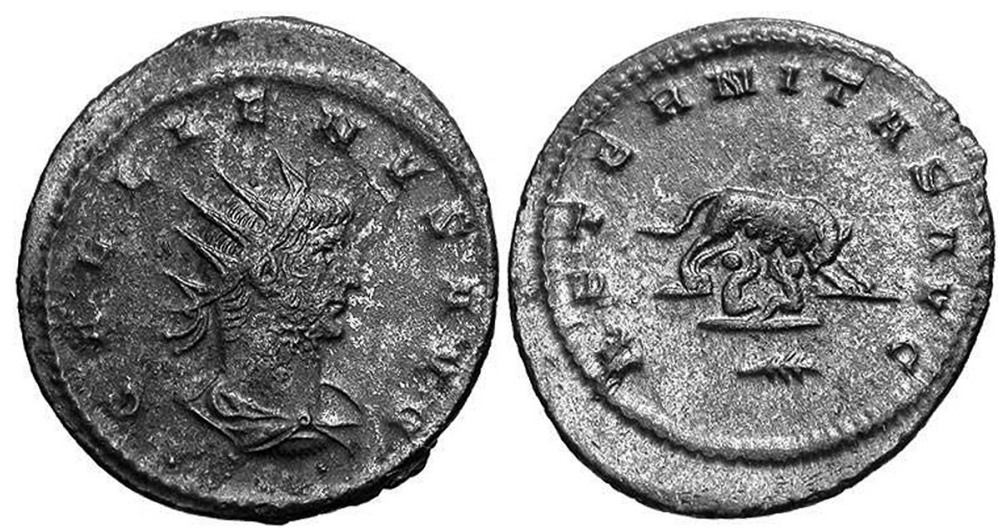

Fig. 2. A silvered antoninianus, 266-267 CE. Obverse: A bust of the emperor Gallienus, with the text GALLIENVS AVG. Reverse: The shewolf suckling Romulus and Remus, with the text AETERNITAS AVG. Photo source: www.vcoins.com

The she-wolf as a symbol of Rome spread to the provinces not only with imperial coins but also with coins minted by Roman legions. After the Marian reforms of 107 BCE the eagle was the only emblem used on the standards of the Roman legions. However, each legion also had its own individual symbol, which was used both in the official iconography of the legions, such as on coins, and in the decoration of the personal belongings of the soldiers. The she-wolf with the twins was the emblem of the Legio II Italica and the Legio XI Claudia. The she-wolf motif was occasionally minted also on the reverse of the $2^{\text {nd }}$ and $3^{\text {rd }}$ century CE coins of the Legio I Italica, and was presented on some military insignia of the Legio VI Ferrata. The emblems of the legions were chosen for different reasons. ${ }^{23}$ With the $I$ and II Italica legions the she-wolf motif can be seen as a reference to their Italian origin. ${ }^{24}$

\section{PROVINCIAL COINAGE}

The she-wolf motif was not only a tool of propaganda to proclaim Roman supremacy in the provinces. The residents of the provinces used it too in order to express their own romanitas, their loyalty to and connection with

${ }^{20}$ RIC II, n. 193; III, n. 649, 734, 997, 1060; IV, n. 15; Dulière 1979, I, 162-176; II, M25-M118; PARISI PresicCe 2000, 50-51.

${ }^{21}$ RIC VII, n. 72, 316; DuLIÈRE 1979, II, M126-M128; AichHolzer 1983, Kat. 294-295; PARISI PresicCe 2000, 51. In Figure $22 a$ (below) is presented the reverse of his coin.

${ }^{22}$ RIC V/1, n. 628. On the aeternitas, see A. ARNALDI: Il motivo dell'aeternitas Augusti nella monetazione di Massenzio. Numismatica e antichità classiche 6 (1977) 271-280; R. ETIENNE: Aeternitas Augusti, aeternitas imperii. In: P. Lévêque - M.-M. Mactoux (eds): Les grandes figures religieuses. Fonctionnement pratique et symbolique dans l'antiquité. Rencontre internationale, Besançon 25-26 avril 1984. Paris 1986, 445-454; K. BALBUZA: Aeternitas - an element of emperor Trajan's self-representation (an outline of the problem). In: H. Kowalski - P. Madejski (eds): Terra, mare et homines. II: Studies in memory of professor Tadeusz Łoposzko. Lublin 2010, 27-32.

${ }^{23}$ Cf. A. von Domaszewski: Die Tierbilder der Signa. In: A. von Domaszewski: Abhandlungen zur römischen Religion. Leipzig 1909, 1-15; O. STOLL: Warum der Storch? Passauer Jahrbuch 52 (2010) 17-46.

${ }^{24}$ Dulière 1979, I, 248-252; R. CioŁeK - J. Kolendo: Legio I Italica on the Coins of Septimius Severus and Gallienus. In T. Derda - P. Dyczek - J. Kolendo (eds): Novae. Legionary Fortress and Late Antique Town. Warsaw 2008, 225-233. 


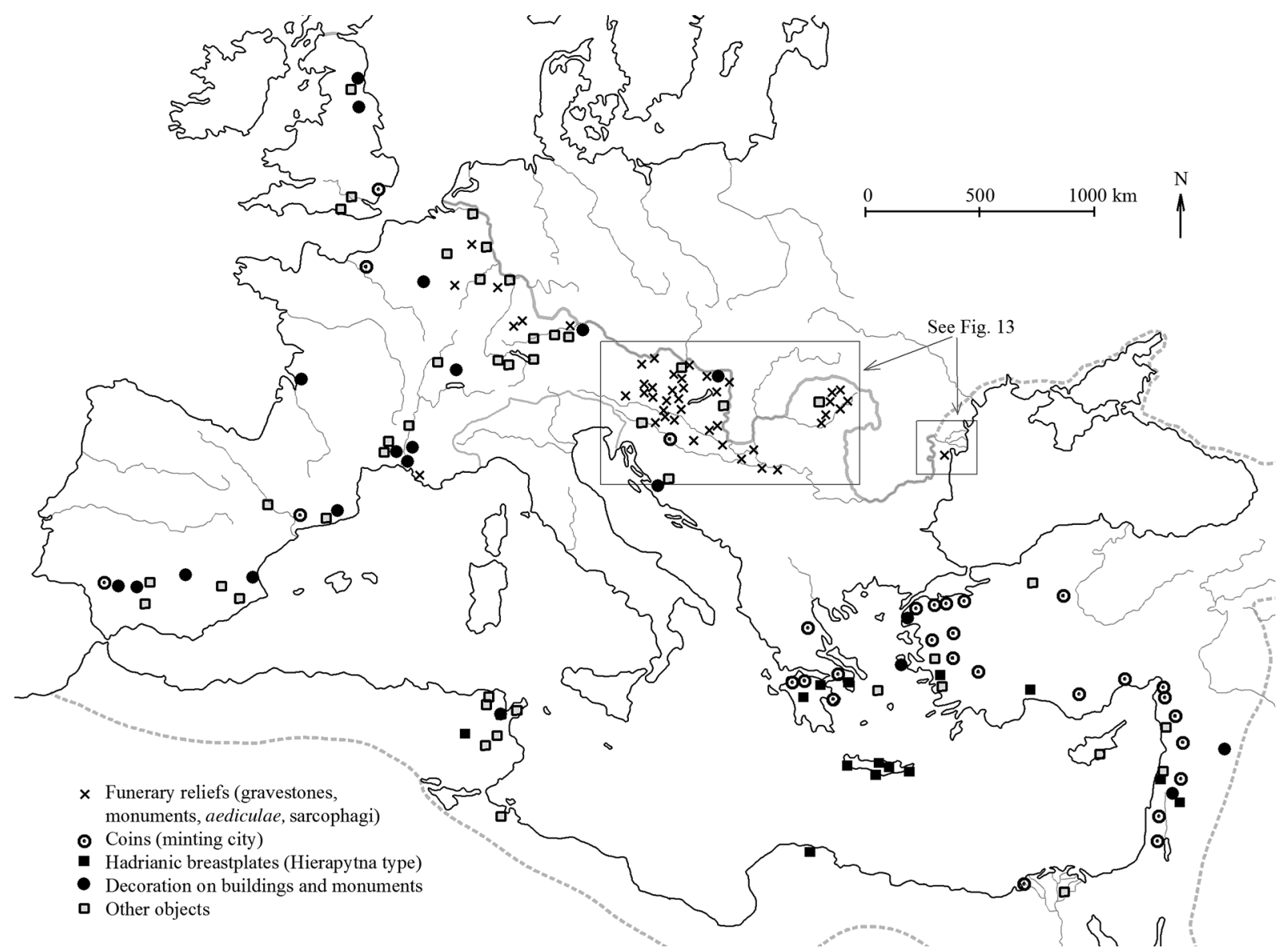

Fig. 3. Map of the provenance of representations of the she-wolf in the Roman provinces. Drawn by the author

Rome. ${ }^{25}$ On the coins of Ilium (Troy), for example, the she-wolf appeared with Aeneas, thus drawing attention to the Trojan roots of Rome. ${ }^{26}$

The she-wolf motifs on provincial coins were mainly copied from Roman coins. The oldest of such coins date from the Augustan Age, ${ }^{27}$ and the minting continued until the fall of the Empire. The geographical distribution of provincial she-wolf coins is worth noting: the vast majority of extant coins were minted in Greece, Asia Minor and the Near East (see Fig. 3). ${ }^{28}$

The she-wolf motif appeared for the first time in Palestine some years after the suppression of the Jewish revolt of Bar Kokhba (132-135 CE) and the re-building of Jerusalem as a Roman colony, named Aelia Capitolina, in $136 \mathrm{CE}$. There are 18 different types of coins with the she-wolf motif known from Aelia Capitolina, ${ }^{29}$ but only one type from other cities of Palestine, Phoenicia or Arabia. ${ }^{30}$ It seems plausible that the she-wolf not only proclaimed the romanitas of Aelia Capitolina but at the same time reminded inhabitants of nearby areas of the consequences of disobedience.

\section{al. 2005, 19-27.}

${ }^{25}$ Cf. G. Williamson: Aspects of identity. In: Howgego et

${ }^{26}$ A. R. Bellinger: Troy. The coins. Troy. Supplementary monograph 2. Glückstadt 1961, 48; SNG n. 1533; AMISANo 2004, 16.

${ }^{27}$ BURNETT et al. 1992, 78, n. 62; 109, n. 259-60; 342, n. 2009.

${ }^{28} S N G$ n. 1331, 1339, 1465, 1475, 1533, 1918, 3069, 3628, 4939, 4948, 4952, 4953, 4985, 4986, 5393, 5394, 5401, 5775, 6187, 6191, 6197, 7444, 7575, 8650; A. KRZYŻANOwSKA: Monnaies coloni- ales d'Antioche de Pisidie. Varsovie 1970, 111-116; Dulıère 1979, I, 230-233; II M29-M118.

${ }^{29}$ L. Kadman: The Coins of Aelia Capitolina. Corpus Nummorum Palaestinensium. 1. Jerusalem 1956, 54-55.

${ }^{30}$ From Neapolis (modern Nablus in the West Bank), minted during the reign of Philip I, 244-249 CE. Y. Meshorer: CityCoins of Eretz-Israel and the Decapolis in the Roman Period. Jerusalem 1985, 52, n. 144-146. 


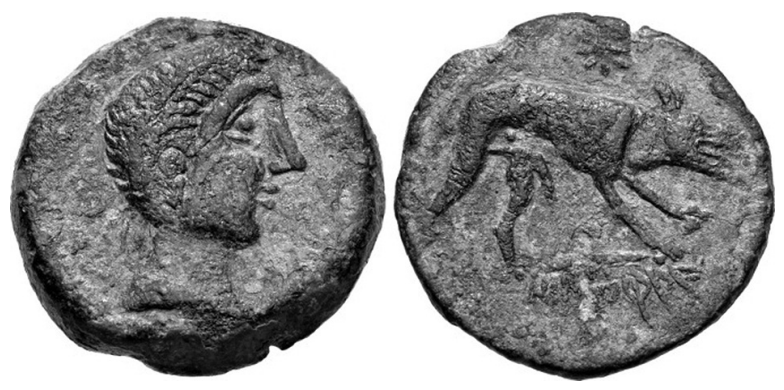

Fig. 4. (LEFT) Bronze coin (as) of Ilerda, minted between 80 and 72 BCE. Obverse: Diademed male head. Reverse: Male wolf. Photo source: www.numisbids.com
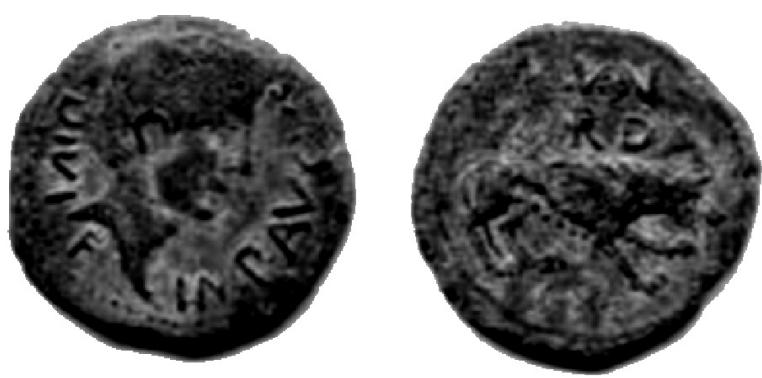

Fig. 5. (RIGHT) Bronze coin (semis) of Ilerda, minted between 27 BCE and 14 CE. Obverse: Head of Augustus, with the text IMP AVG / DIVI F. Reverse: She-wolf, with the text MVN / [ILE]RDA.

Photo source: www.identificacion-numismatica.com

The use of the Lupa Romana on coins was probably restricted. When analyzing the she-wolf coins of $2^{\text {nd }}$ and $3^{\text {rd }}$ century Asia Minor, E. Dąbrowa concludes that only cities which were involved at the time with the Roman central government or the Imperial house for some special reason seem to have been given the privilege of minting coins with the she-wolf motif. In some cities, such as Ancyra, Ephesus, Hierapolis and Philadephia, she-wolf coins were minted to celebrate the inauguration of a temple built for the emperor, through which act the city got the title of neokóros, "temple-warden". In the Cilician towns of Tarsus and Anazarbus the coins were minted when the cities were granted higher administrative status. ${ }^{31}$

Dąbrowa's theory gets support from the fact that in other provinces too the she-wolf motif is found mostly on the coins of Roman colonies or cities re-founded by the Romans; a good example is the case of Aelia Capitolina mentioned above. Even though local magistrates were free to choose the designs to be used on coins, ${ }^{32}$ the use of images with a strong symbolic value was probably controlled in official contexts, such as coinage. Therefore, in order to avoid inflation of the value of the she-wolf motif, it is probable that only certain cities were granted the privilege of minting coins with the Lupa image, as a symbol of their particular romanitas. This can be seen as a part of the divide et impera policy practiced by the Romans. By underlining the emperor's favor towards certain cities, Rome could gain loyal allies and prevent extensive anti-Roman alliances.

Some provincial cities had had a special relationship with the wolf even before the Roman Era, and the use of the Lupa Romana can be seen as a natural continuation of that. For example, the Hispanic town of Ilerda had a male wolf as its traditional emblem (Fig. 4). However, when Ilerda became a Roman municipium in the middle of the $1^{\text {st }}$ century BCE, the male wolf was replaced by a female one (without infants, Fig. 5). The new emblem must be explained as a reference to the new status of the town and as an expression of loyalty to Rome. ${ }^{33}$

\section{IMPERIAL CUIRASSES}

Official portraits were an important way for Roman emperors to control their public image. From the Augustan age onward, cuirassed imperial statues were displayed in order to draw attention to the emperor's role as commander-in-chief. The iconography of the breastplates, consisting of mythological and/or historical elements, was carefully considered.

${ }^{31}$ E. DĄBRowA: Lupa Romana sur les revers des monnaies des villes d'Asie Mineure (II - III s. après J. - C.). In: H. Heftner-G. Dobesch: Ad Fontes! Festschrift für Gerhard Dobesch. Wien 2004, 479-483. Cf. R. ZIEGLER: Münzen Kilikiens aus kleineren deutschen Sammlungen. München 1988, n. 699 and 1046; B. Burrell: Neokoroi: Greek Cities and Roman Emperors. Leiden 2004, 309-311; D. O. A. KLOSE: Festivals and games in the cities of the East during the Roman Empire. In: HowgEgO et al. 2005, 144.
${ }^{32}$ C. J. Howgego: Greek Imperial Countermarks: Studies in the Provincial Coinage of the Roman Empire. London 1985, 83-99.

${ }^{33}$ L. Villaronga: Las monedas ibéricas de Ilerda. Barcelona 1978, 16; Evans 1992, 86; BuRnETt et al. 1992, 109. Ilerda is modern Lleida in Catalonia. 


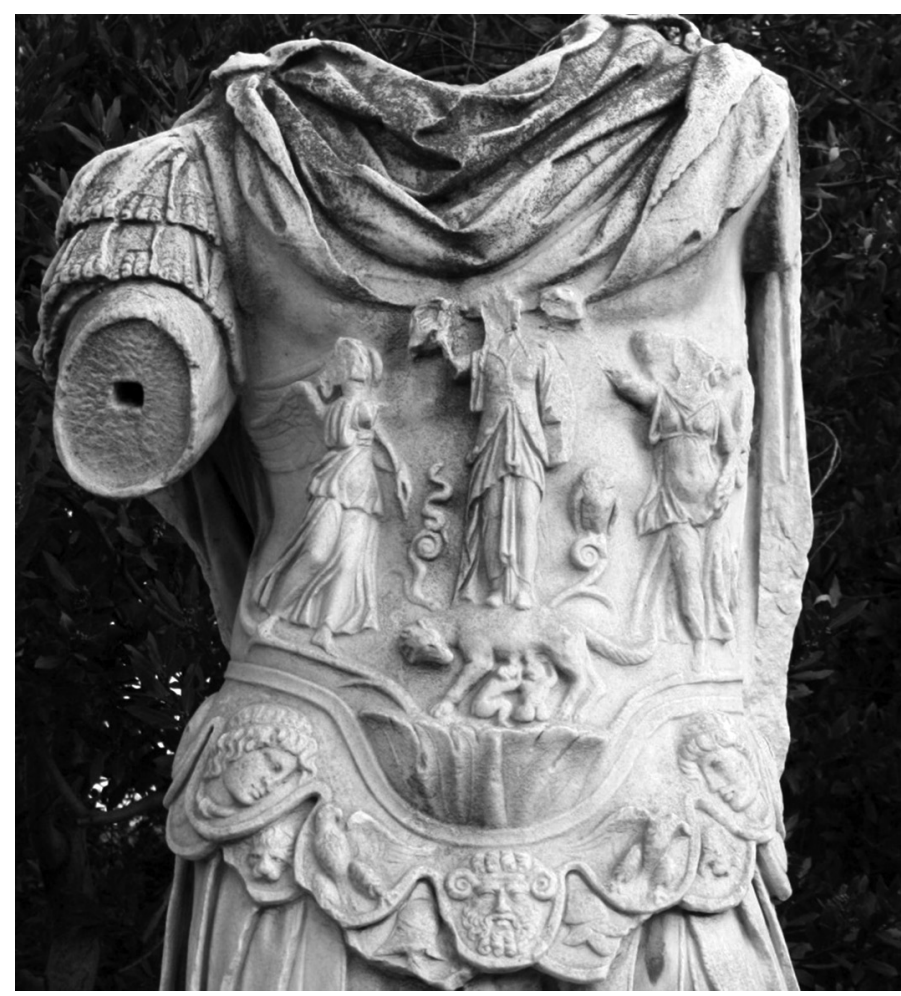

Fig. 6. Torso statue of the emperor Hadrian at the Agora of Athens. Early $2^{\text {nd }}$ century CE. Photo: G. Dall'Orto

On the cuirasses of the imperial statues of the Flavian dynasty and of the Emperor Trajan the she-wolf had acted straightforwardly as an emblem of Rome,$^{34}$ but Hadrian elevated the she-wolf symbolism to another plane. Almost twenty statues of Hadrian (not all of them in perfect condition) and some fragments of statues have been found, which all have a similar scene on the breastplate: winged Victories flank the goddess Athena or the Palladium (the safeguard statue of Troy which, according to legend, was brought to Italy by Aeneas), who is standing on the back of a she-wolf (Fig. 6). These complete or fragmented cuirasses of the so called Hierapytna type ${ }^{35}$ (or "eastern Hadrianic breastplate type", as it was named by R. A. Gergel) constitute the largest single group within the entire corpus of Roman imperial cuirassed statues. It is interesting to notice that one cannot find two identical breastplates among them. However, on the grounds of the strong consistency in the detail, all the statues presumably derive from one or more prototypes, which possibly originated in Athens. ${ }^{36}$

The background of the pictorial motif can be found on the breastplates of Hadrian's predecessors. Imperial cuirasses with Victory crowning the Palladium had been made since the Augustan Age. ${ }^{37}$ Hadrian's innovation was to introduce the Roman she-wolf into the scene as the pedestal of the Palladium, or rather of the goddess Athena herself. ${ }^{38}$ The she-wolf can be seen indisputably as the symbol of Rome, but the figure of Athena and the whole scene can be interpreted in different ways.

J. M. C. Toynbee's suggestion that the Palladium and the Lupa are a double representation of Rome itself $^{39}$ is not convincing for two reasons. First, all the copies of the statues have been found in the Greek-speaking eastern

${ }^{34}$ Dulière 1979, I, 135-136; II, 12, 27; Parisi PresicCe 2000, 39. Cf. B. Woytek: Lupa Traiana: die traianischen Kleinbronzen mit Wölfin. Numismatische Zeitschrift 119 (2012) 7-30.

${ }^{35}$ On the grounds of one of the best preserved statues, which was found in Hiérapytna, Crete, in 1864-65. Istanbul Archaeological Museum, inv. 50.

${ }^{36}$ Gergel 2004, 371-375; Bergmann 2010, 234-235; $258-288$.
${ }^{37}$ C. Vermeule: Hellenistic and Roman cuirassed statues. Berytus 13 (1959) 10

${ }^{38}$ K. STEMMER: Untersuchungen zur Typologie, Chronologie und Ikonographie der Panzerstatuen. Berlin 1978, 160-161; DuLIÈRE 1979, I, 199; II, 13-26bis; AichHolzer 1983, Kat. 228/1-5, 7-10.

${ }^{39}$ J. M. C. ToynbeE: Picture-language in Roman art and coinage. In: R. A. G. Carson-C. H. V. Sutherland (eds): Essays in Roman Coinage Presented to Harold Mattingly. Oxford 1956, 213 n. 2. 
part of the Empire: Greece, Asia Minor, Syria, and Africa (see Fig. 3), where people would more probably have connected the figure of Athena to the Greek tradition, not to the Roman legend of Aeneas, who had fled from Troy. Secondly, in some copies the female figure does not show the archaic fashion which was typical of the Palladium but rather has the appearance of Athena, especially as the accompanying owl and snake are known to be attributes of the goddess, not of her archaic statue. ${ }^{40} \mathrm{I}$ am inclined to believe that the female figure presents Athena, the symbol of Athens and Greek culture in general, and thus the pictorial motif can be seen to refer to both Roman (the she-wolf) and Greek (Athena) tradition.

These breastplates are regarded as an expression of Hadrian's philhellenism - even though their exact dating and the context of the propaganda are still a matter of debate. ${ }^{41}$ The placing of the she-wolf under Athena could be simply for aesthetic reasons and because of the shape of the cuirass, as suggested by B. Bergmann ${ }^{42}$ but it might include another philhellenic connotation, implicitly expressing Hadrian's respect for Greek culture. ${ }^{43}$ The group could even be seen as a visual parallel to Horace's aphorism Graecia capta ferum victorem cepit, "captive Greece captured her uncivilized conquerors". ${ }^{44}$

\section{DECORATION ON BUILDINGS AND MONUMENTS}

Reliefs representing the she-wolf were used in the decoration of various public buildings and monuments in the provinces. Funerary monuments will be discussed separately, although in some cases there are obvious similarities between the two groups.

The representations of the Lupa in the pediment reliefs of some aediculae, small shrines, found in Roman military camps, were probably associated with the imperial cult (as in a $2^{\text {nd }}$ century shrine from Burnum, Dalmatia) $)^{45}$ and the cult of Roma Aeterna (in a $2^{\text {nd }}$ century shrine from Coria, Britannia; Fig. 7) ${ }^{46}$ Other similar reliefs found in military camps, for instance the one found in Castra Regina (Regensburg), Raetia, probably belong to funerary aediculae. ${ }^{47}$ The choice of the she-wolf motif in these reliefs could not have been based on the emblems of the legions settled in the camps. It must also be noted that even though the wolf in the martial context was usually male (lupus Martius), ${ }^{48}$ all the known representations of the wolf from provincial military camps depict the she-wolf, Lupa Romana. Therefore the she-wolf should not be understood as a manifestation of Roman military power but as a reference to the birth myth and thus a symbol of romanitas. Nor can the images of the she-wolf be seen as a tool of propaganda proclaiming Roman supremacy to the inhabitants of the provinces, because military camps were not public places open to civilians; their message as a symbol of Rome and an expression of loyalty was directed to the soldiers themselves.

The she-wolf was depicted in some reliefs decorating the outer walls of the amphitheaters of Nemausus (Nîmes) and Arelate (Arles) in Gallia Narbonensis and the theater of Ilium Novum (Troy) in Asia Minor. ${ }^{49}$ The

${ }^{40}$ Gregel 2004, 405. Cf. F. CANCIANI: Athena / Minerva. In: LIMC 2. Zürich 1984, 1091-1092. BERGMANN (2010, 231), on the other hand, supports the identification as the Palladium.

${ }^{41}$ Gregel (2004, 377-386 and 392-400) believes that the first breastplates were carved as early as the first years of Hadrian's reign (between 117 and $123 \mathrm{CE}$ ) to celebrate his succession to the throne and his role as the protector of the whole Empire, and that later statues rather promoted the idea of the coequal role of the western and eastern parts of the Empire. This equality would have been emphasized especially after the founding of the Panhellenion, a league of Greek cities, in 131/132 CE. BERGMANN (2010, 252-258) suggests that all the statues were carved after $131 \mathrm{CE}$, representing Hadrian as Panhellenios, the protector of the Panhellenion, while some of the statues simultaneously proclaim the suppression of the Jewish revolt of Bar Kokhba (132-136 CE). For other suggestions of the context, see Dulière 1979, I, 204-208; GREGEL 2004, 404-405.

42 Bergmann 2010, 239.

${ }^{43}$ M. Wegner: Hadrian. Berlin 1956, 68; G. W. H. HaRRISON: The Romans and Crete. Amsterdam 1993, 240.

${ }^{44}$ Hor. epist. $2,1,156$. Translated by A. S. Kline.
${ }^{45}$ Arheološki muzej Zadar, inv. no. A10200. Giunio 2005, 221-222. The aedicula dates from the middle of the $2^{\text {nd }}$ century and thus the pictorial motif probably has nothing to do with the Legio XI Claudia, which was settled in Burnum in 9-70 CE.

${ }^{46}$ Corbridge Roman Site, inv. n. CO 23361. CSIR Great Britain I,1, 37. It has also been suggested that the relief is part of a gravestone (BURGER 1964, 58, n. 39) or of a decoration of a fortress (DULIÈRE 1979, I, 228; II, 114).

${ }^{47}$ Historisches Museum, Regensburg, Inv. Lap.119; found in the praetorium of Castra Regina (Regensburg), dating from 200250 CE; CSIR Deutschland I, 1. Bonn 1973, n. 456; KEMPCHEN 1995, 216 , n. 85. A relief from a funerary aedicula has been found in Cristeşti, Dacia, too. Muzeul Judeţean Mureş, inv. 4900, dating from 100-300 CE; Pop: 1971, 178-179, n. 5, Fig. 5.

${ }^{48}$ E.g. Liv. 10,27,9. Cf. Verg. Aen. 9,566; Sil.13,130-133.

${ }^{49}$ DuliÈRE 1979, I, 228-229; II, 116, 119. Arelate was colonized by Caesar's veterans of the Legio VI Ferrata, which had shewolves in some of their military insignia. However, since all the extant she-wolf motifs date from the Empire, the she-wolf of the legion has probably nothing to do with the one depicted on the wall of the arena. 
amphitheater represented the idea of romanitas in the provinces, which makes the presence of the she-wolf understandable. ${ }^{50}$ Another typically Roman monument was the arch. The early $3^{\text {rd }}$ century CE Porta Martis in Durocortorum (Reims), Belgica, is decorated with scenes of Roman mythology and local agricultural work, the she-wolf appearing on the ceilings of the arcades. ${ }^{51}$ The arch, which was probably built by wealthy locals and dedicated to

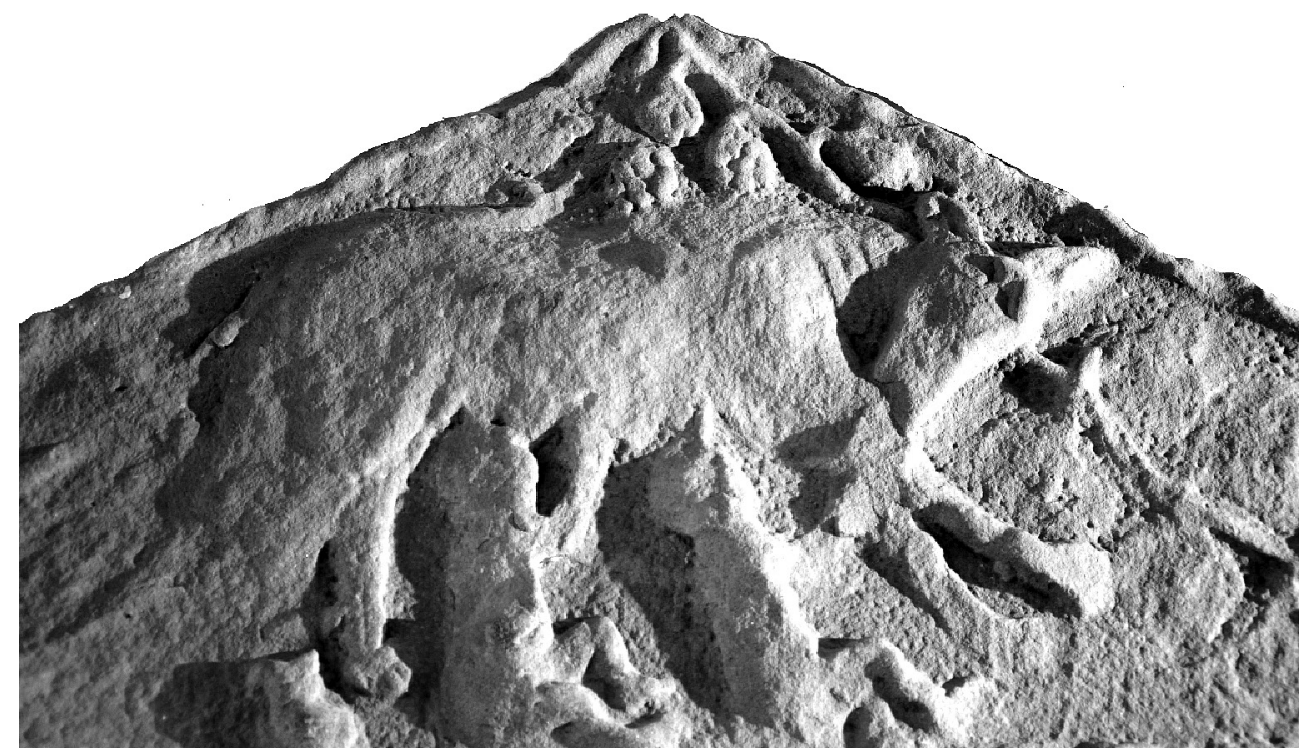

Fig. 7. Pediment relief of a shrine of Roma Aeternain Coria, Britannia. Middle of the 2nd century CE. Photo: G. Plowright

Mars Camulos, the god of war combining Roman and Celtic traditions, also symbolized the union between Rome and the inhabitants of Durocortorum. ${ }^{52}$ The she-wolf block from Aventicum (Avenches), Germania Superior, probably belongs to an honorary, if not to a funerary, monument (Fig. 14, below) ${ }^{53}$; see parallels among funerary monuments discussed below. Reliefs are also known from a fountain, ${ }^{54}$ from a small temple, ${ }^{55}$ and from some other unidentified buildings. ${ }^{56}$

There are no extant fragments of ancient wolf statues from the Roman provinces, but some inscriptions prove that statues of the she-wolf with the twins had been erected in public places outside Rome, too. ${ }^{57}$ Such inscrip-

${ }^{50}$ D. L. Bomgardner: The Story of the Roman Amphitheatre. Glasgow 2000, 42; G. LegrotTAGLIE: Il sistema delle immagini negli amfiteatri Romani. Bari 2008, 167-168.

${ }^{51}$ DuliÈre 1979, II, 118; DARDENAY 2012, 252, n. L22.

52 F. LeFÈVRE: Reflexions à propos des sculptures de la « Porte de Mars » a Reims. In: R. Chevallier (éd.): Le monde des images en Gaule et dans les provinces voisines. Paris 1988, 156-157.

${ }^{53}$ M. BossERT: Die Skulpturen. In: J. Morel (éd.): Le Palais de Derrière la Tour à Avenches. 2. Cahiers d'archéologie romande 118. Lausanne 2010, 127-132; I. VERGA: La louve d'Avenches et ses parallèles transalpins. Université de Neuchâtel (MA thesis). CSIR Schweiz I, 1, 43. A. Sz. Burger (1964, 58-59) regards the reliefs of Aventicum and Coria (Britannia, see above n. 46) as parts of funerary monuments.

${ }^{54}$ From Italica, Hispania Baetica, Museo Arqueológico de Sevilla, Inv. IG 125. M. L. LozA AzUAGA: La decoración escultórica de fuentes en Hispania. Malaga 1993, 259, n. 42.

${ }^{55}$ From Saintes, Gallia Aquitania. Musée Archéologique de la Ville de Saintes, Inv. 1949.4.13A. Cf. D. TARDY: Le décor archi- tectural de Saintes antique. II. Aquitania supplement 7. Bordeaux 1994, 99-107.

56 1) From Glanum, Gallia Narbonensis. Musée Calvet, Avignon, inv. G201; 2) From Haurân, Syria. The National Museum of Damascus, inv. n. 144 / 228. DuLIÈRE 1979, II, 121. The authenticity of a relief from Divio (Dijon) representing a female wolf with only one cub is uncertain. It is probably a modern copy from the $16^{\text {th }}$ or $17^{\text {th }}$ century, as suggested by S. DEYTs (Les antiques de 1'Hotel de Vesvrotte à Dijon. RAE 34 (1983) 340-343). Cf. Dulière 1979, II, 115; DARDENAY 2012, 294, n. L201.

${ }^{57}$ G. SAMOnATI: Menzioni epigrafiche della Lupa Romana. In: Amor di Roma. Roma 1956, 381-384; G. SAmonati: Lupa. Dizionario Epigrafico di Antichità Romana. IV. Roma 1957, 2198 2200; Dulière 1979, I, 216-226; A. BALIL: Lupa Romana. El culto a la Loba en Hispania. Boletin del Seminario de Estudios de Arte y Arqueologia 51 (1985) 263-265; PICARD 1987, 257-263; DARDENAY 2010 b, 86-89. 


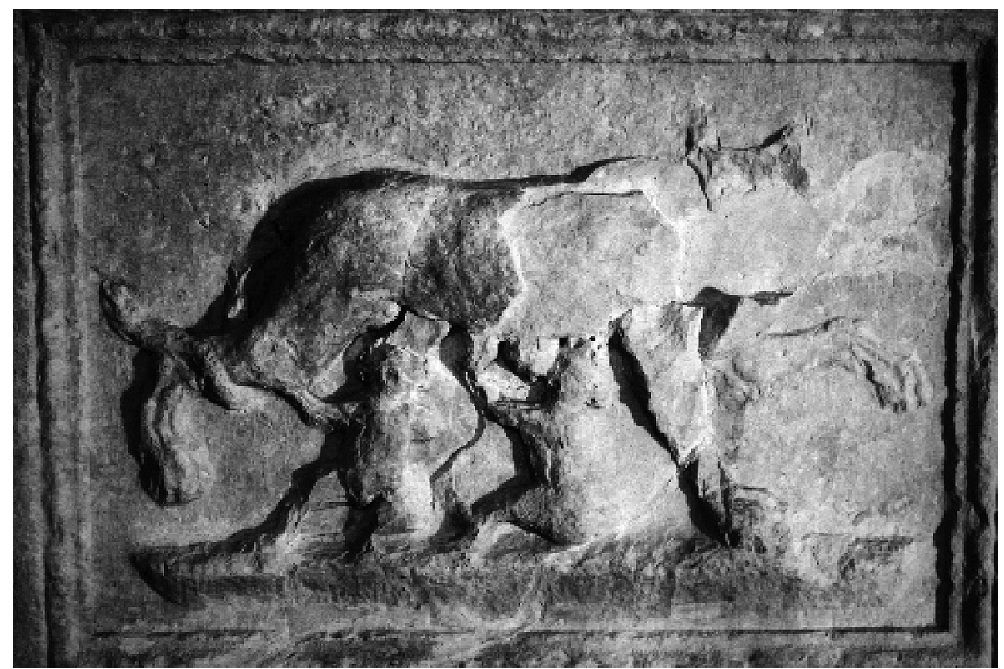

Fig. 8. Front of the altar from Asseria, Dalmatia. Middle of the $2^{\text {nd }}$ century CE. Photo source: GiunIo 2005, Fig. 8.

tions have been found in two provinces, namely Hispania (Singilia Barba) ${ }^{58}$ and Africa (Vina, ${ }^{59}$ Gightis ${ }^{60}$ Flavia Cillium ${ }^{61}$ and Hauâria). ${ }^{62}$ According to C. Dulière, the statues can be connected with the status of municipium, which granted full citizenship rights in all these towns. ${ }^{63}$ There also seems to have been a statue of the Lupa Romana on the island of Chios at the beginning of the $2^{\text {nd }}$ century BCE, ${ }^{64}$ which, however, was then outside the Roman borders. Furthermore, two dedications to Lupa Romana or Lupa Augusta from Hispania (Baetulo ${ }^{65}$ and Epora ${ }^{66}$ ) might indicate the existence of a she-wolf statue. These two dedications are the only surviving indications that the Lupa might have been an object of actual worship. However, since the dedicators are seviri Augustales, who served the imperial state cult, it is obvious that the dedications belonged to this cult too.

Two altars with reliefs representing the myth of Romulus and Remus should be examined in the same context as the above-mentioned inscriptions, because they too indicate the strengthening of the state cult from the $2^{\text {nd }}$ century CE onwards. An altar from Asseria, Dalmatia, has a relief of the Lupa on the front, and reliefs of a sac-

${ }^{58}$ CIL II 5063 = ILS 6912: M. Cornelius Primigenius Sing(iliensis) / ob beneficium quod ab ordine Sing(iliensium) / locum acceperam / inquo statuam ponerem / M. Corneli Saturnini f(ilii) mei / lupam cum infantibus duobus / d(ono) d(ederunt). Singilia Barba is modern Antequera in Andalusia.

${ }^{59}$ CIL VIII 958 = ILS 6819: Numini Augustorum Sacrum / C. Aurelius Saturninus Papiria (tribu) Cilonianus / II vir inlata rei p(ublicae) II viratus honoraria summa / amplius de suo signum lupae cum insignib(us) / suis posuit et expostulante populo diem ludo/rum scaenicorum edidit d(ono) $d($ edit). Vina is located near modern Nabeul in northeastern Tunisia.

${ }^{60}$ CIL VIII 22699: [Q. Servaeus Q. f(ilius) Quir(ina)] / Macer adlectus/ in quinq(ue) dec(urias) a / divo Hadriano / [l]upam $[a]$ eream / quam [ad o]rnamen $[t] /$ um municipii $[p]$ romiserat cum / [Ro]mulo et Remo / de[dit] idemq(ue) dedic(avit). Cf. H.-G. Pflaum: Les juges des cinq décuries originaires d'Afrique romaine. Antiquités africaines 2 (1968) 162-163. Gightis is modern Boughrara in southeastern Tunisia.

${ }^{61}$ CIL VIII 210: Coloniae Cillitanae / Q. Manlius Felix C. filius Papiria (tribu) receptus post alia arcum quoque cum insignibus colo[niae] / solita in patriam liberalitate erexit ...virtute / divina $d$ (ominorum) n(ostrorum) Constantini et Licini inv(i)c(torum) / semp(er) Aug(ustorum) ornamenta liberta(tis) restituta et vetera civi/ tatis insignia... According to Dulière (1979, I, 224-225) and SAMONATI (1957, 2200), vetera civitatis insignia refer to the she-wolf with Romulus and Remus. Flavia Cillium is modern Kasserine in western Tunisia.

${ }^{62}$ CIL VIII 12220 = ILS 6820: [signum] / lupae cum [gemell]/ is suis du[obus ex] / summa hon[oraria] / duoviratus suife/cit idemq(ue) dedicavit / lupas. The name of the town is unknown. The location is near modern Kairouan in central Tunisia. G.-C. PICARD (1987, 259-260) suggests on the grounds of a base which was discovered without any inscription that there was a she-wolf statue in Makhtar (central Tunisia), too.

${ }^{63}$ Dulière 1979, I, 216-224; PiCARD 1987, 258-259.

${ }^{64}$ L. MoretTI: Chio e la Lupa Capitolina. Rivista di filolo-

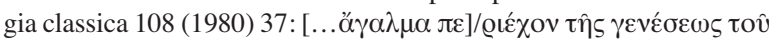

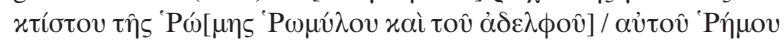

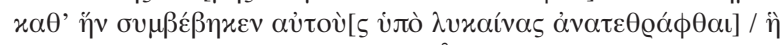

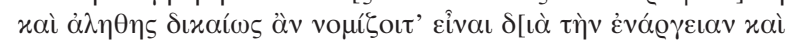

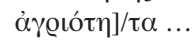

${ }^{65}$ CIL II 4603: Lupae Augustae / L. Visellius Evangeli / lib(ertus) Tertius / IIIIIIvir Aug(ustalis). Baetulo is modern Badalona in Catalonia.

${ }^{66}$ CIL II 2156 = ILS 6913: Lupae Romanae / M. Valerius Phoebus / VI vir Aug(ustalis). Epora is modern Montoro in Andalusia. 


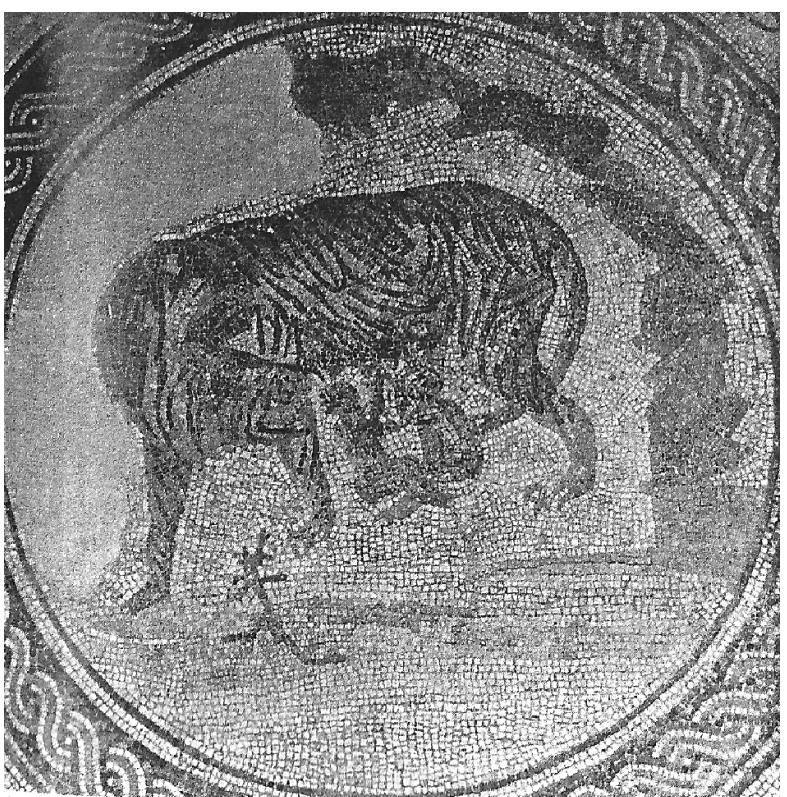

Fig. 9. (LEFT) She-wolf mosaic from Alcolea, Hispania Baetica $2^{\text {nd }}$ century CE. Photo source: Museo Arqueológico de Córdoba

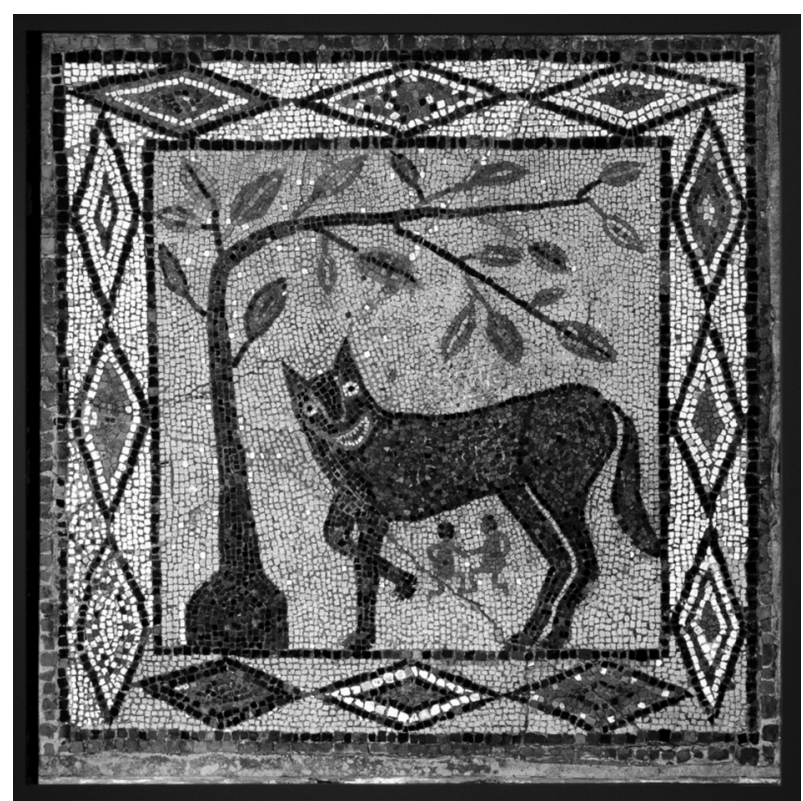

Fig. 10. (RIGHT) She-wolf mosaic from Aldborough, Britannia. $4^{\text {th }}$ century CE. Photo source: (C) Leeds Museums and Galleries

rificial bull and the act of libation on the sides. The she-wolf is depicted in an exceptional position, with one foreleg and one rear leg raised (Fig. 8). ${ }^{67}$ An altar from Bölcske, Pannonia Inferior, with the image of the she-wolf, is inscribed with the dedication of a praefectus equitum to Jupiter. ${ }^{68}$ As the she-wolf was usually sacred to Mars (Lupa Martia), the combination of the image of the Lupa and the altar of Iuppiter could mean that the she-wolf was in this case regarded simply as the symbol of the Roman Empire, without its mythological and religious overtones.

In the private sphere, the she-wolf motif appears in mosaics and murals. Four mosaic floors have been discovered in rustic villas in Hispania (dating from the $3^{\text {rd }}$ century CE) and one in northern Africa (dating from the $4^{\text {th }}$ century). ${ }^{69}$ The she-wolf in these five mosaics is depicted in the traditional position. The striped fur of the animal in the Spanish mosaic of Alcolea (Fig. 9) may seem exceptional, but in fact such a representation is also found in the Roman mosaics of Ostia and Larino. ${ }^{70}$ In a $2^{\text {nd }}$ century CE mural found in Brigetio, Pannonia, ${ }^{71}$ and in some of the mosaics, the she-wolf is accompanied by other scenes of Roman mythology, such as Aeneas fleeing from Troy or the encounter of Mars and Rhea Silvia. ${ }^{72}$ The mythological motifs can be seen as an expression of personal loy-

${ }^{67}$ Arheološki muzej Zadar, inv. no. A10201. K. A. GIUNIO: Monumentalni žrtvenik s prikazom Vučice s Romulomi Remomi scenama žrtvovanja iz Aserije. Asseria 1 (2003) 133-155; GIUNIO 2005, 219-221. Asseria is modern Podgrađe, near Benkovac in Croatia.

${ }^{68}$ I(ovi) O(ptimo) M(aximo) / ala I Thrac(um) / vet(erana) cui pr(a)elest T(itus) Venno/nius Avetus / praef(ectus) eq(uitum). Soproni Sándor Lapidarium, Bölcske, Inv.10 (Inv. SzWM 2002.5.32). J. Beszédes-Zs. MrÁv-E. TóTH: Die Steindenkmäler von Bölcske Inschriften und Skulpturen - Katalog. In: Á. Szabó-E. Tóth (Hrsg.) Bölcske. Römische Inschriften und Funde. Libelli archaeologici Ser. Nov. 11. Budapest 2003, 138-139, n. 32.

${ }^{69}$ DuliÈRE 1979, I, 116-117; II, 141-144; D. FerNÁNDEZGaliano: Mosaicos hispánicos de Esquema a Compás. Guadalajara 1980, 39-41; J. M. BlázQuEZ: Mosaicos romanos de Cordoba, Jaen y Malaga. Corpus de mosaicos de España 3. Madrid 1981, 43-46 and 72-73; J. M. Blázquez Martinez-G. López Monteagudo-M. L. NeIRA JimÉNEZ-M. P. SAN Nicolás PEDRAZ: La mitologia en los mosaicos hispano-romanos. Archivo Español de Arqueologia 59 (1986)
130-131, fig. 60; L. ABAD CASAL: El mosaico de Fáustulo y los orígenes de Roma. In: El mosaico romano de «los orígines de Roma». Barcelona 2004, 67-83; DARDENAY 2010b, 89-93; DARDENAY 2012, 245, n. L29; 295-296, n. L202-L205.

${ }^{70}$ Dulière 1979, II, 139-140; S. Guidone: Il Mosaico «della lupa» di Larino. In: C. Angelelli (ed.): Atti del XIV colloquio dell'Associazione Italiana per lo Studio e la Conservazione del Mosaico. Tivoli 2009, 439-448.

${ }^{71}$ E. Bíró: A brigetiói falfestmény (Die Wandmalerei von Brigetio). ArchÉrt 120 (1993) 37-45; DARDENAY 2012, 296, n. L206. Brigetio is modern Szőny in Hungary. It is probably coincidental that the Legio XI Claudia, which had the she-wolf as its emblem, was settled in Brigetio in 101-104 CE.

72 These other scenes of the mythic origins of Rome were commonly depicted in provincial art, too, even if not as frequently as the Lupa Romana. Cf. P. NoelKe: Aeneasdarstellungen in der römischen Plastik der Rheinzone. Germania 54 (1976) 409-439; DARDENAY 2010a; DARDENAY 2012; ALBERTSON 2012. 
alty to Rome. ${ }^{73}$ Whereas being Roman of itself meant a higher social status, this kind of decoration could also have been chosen in order to emphasize a person's rank among his neighbors and friends.

A $4^{\text {th }}$ century CE mosaic found in Aldborough, Britannia (Fig. 10), is strikingly different from all the other extant representations, in both general style and the detail. The position of the she-wolf, standing with one foreleg bent, and the size of the animal in relation to the tiny infants are exceptional. The mosaic was regarded as a forgery by K. Parlasca and D. S. Neal, ${ }^{74}$ but its unsophisticated appearance should rather be explained by poor craftsmanship; the mosaic was probably based on an oral or literary version of the legend and made without any visual models available.

\section{MILITARY EQUIPMENT AND PERSONAL OBJECTS}

The she-wolf appears as a decoration on some military equipment found in the northwestern border regions of the Roman Empire. It was the main decorative motif on the scabbard of the so-called Fulham sword, a $1^{\text {st }}$ century gladius which was found in the River Thames in Fulham, London (Fig. 11). ${ }^{75}$ The image also appears on some

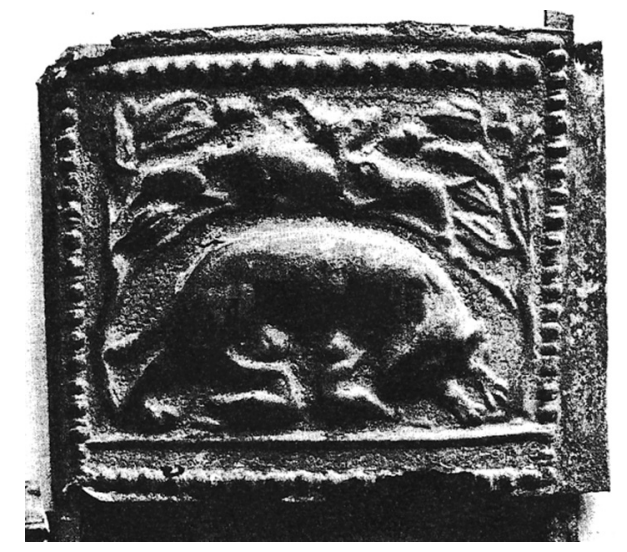

Fig. 11. (LEFT) Detail of the scabbard of the Fulham sword, Bronze plate. $1^{\text {st }}$ century CE. Photo source: British Museum

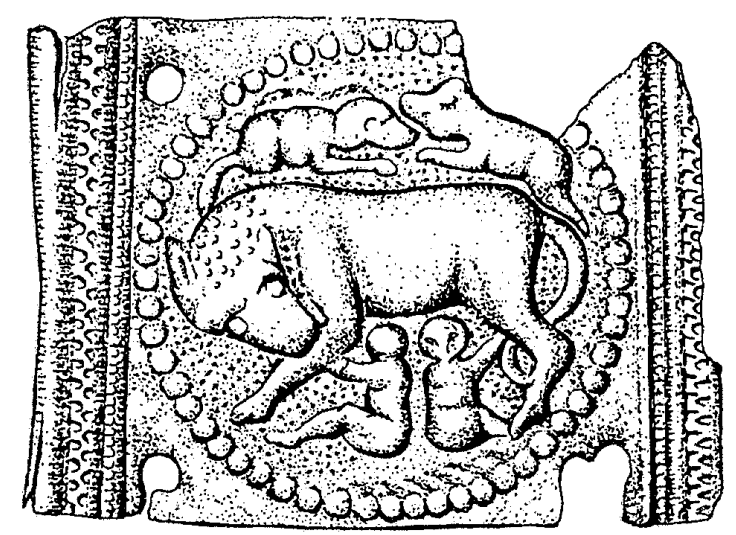

Fig. 12. (RIGHT) Decorated belt plate from Mogontiacum, Germania Superior. $1^{\text {st }}$ century CE. Photo source: KüNZL 1996, Abb. 13.1.

cingula, sword belts. Belt decorations made of bronze have been found especially in Vindonissa, Germania Superior, (8 items) where the Legio XI Claudia was stationed between the years 70 and $101 \mathrm{CE}$; the she-wolf was the emblem of this legion. ${ }^{76}$ Isolated examples of belt plates have been found in Mogontiacum (Mainz), Germania Superior, too (Fig. 12), as well as in the provinces of Britannia, Germania Inferior and Raetia. ${ }^{77}$ In these cases the choice of motif cannot be explained by the emblems of the legions, but rather by individual soldiers' own preference.

${ }^{73}$ DARDENAY 2010a, 204-206.

${ }^{74}$ K. PARLASCA: Mosaikforschungen. MDAIR 65 (1958) 182; D. S. NeAL: Observations on the mosaic from Micklegate Bar, York, and the Wolf and Twins mosaic, Aldborough, N. Yorks. Mosaic 9 (1983) 2. On the other hand, the authenticity of the mosaic is supported, for example, by R. LING (Venison and the wolf again. Mosaic 10 [1984] 18) and P. WITTS (The Aldborough wolf and twins mosaic: Roman or Victorian? Roman Antiquities Section of the Yorkshire Archaeological Society Bulletin 13 [1996] 20). Witts says reasonably that "if a forger had deliberately set out to create a 'new' Roman mosaic, he would surely have been able to draw the animal more accurately." The authenticity can be supported by the fact that after the discovery of the Aldborough she-wolf mosaic (found about 1842, published in Gent's Mag 1862, ii, 614 and Leeds Philosophical and Literary Society Report 43 [1862-63] 13; published in detail in H. E. Sмітн: Reliquiae Isurianae. Appendix, 1867), some parallels to its naïve style have been found among other mosaics in Roman Britain. Compare the Venus mosaic of Rudston (found in 1933; D. S. NEAL-S. R. Gosh: Roman Mosaics of Britain. I. London 2002, 353-356, mosaic 143.2; P. WitTs: Mosaics in Roman Britain. Stroud 2005, 149, fig. 73).

${ }^{75}$ British Museum, inv. 1883 4-7.1. DuLIÈRE 1979, II, 159; DARDENAY 2012, 304, n. L242.

${ }^{76}$ C. Dulière: Beschlagbleche aus Bronze mit dem Bild der römischen Wölfin. Gesellschaft pro Vindonissa Jahresbericht 1964, 5-14. Vindonissa is modern Windisch in northern Switzerland. ${ }^{77}$ KÜNZL 1996, 406-411; DARDENAY 2012, 305-307, n. 
Among ornaments and other objects of everyday use, the she-wolf can be seen on belt plates and buckles used for clothing, for example. ${ }^{78}$ They are usually made of bronze, but a silver buckle, fibula, has also been preserved. ${ }^{79}$ Some bronze statuettes representing a she-wolf are also known. Terracotta objects include figurines, decorative plaques, lamps and different types of vases. ${ }^{80}$ The image is usually traditional, with the Lupa in the trapezoidal composition and the twins under her. Some stylistic varieties appear on gems, where the Lupa and the twins are occasionally accompanied by other elements of the myth, such as the fig-tree or the shepherd Faustulus, or by the goddess Roma ${ }^{81}$ However, it must be noted that the origin of gems, wherever they were found, is usually unknown. In personal belongings the she-wolf as the decorative motif was an individual's own choice, a way of expressing the owner's Roman identity, not something influenced or controlled by the authorities.

\section{GRAVESTONES AND FUNERARY MONUMENTS}

The she-wolf appeared on Roman grave-altars and ash-chests after the middle of the $1^{\text {st }}$ century CE. About thirty such funerary reliefs have been preserved, found in Rome or nearby, dating from the second half of the $1^{\text {st }}$ century. At the end of the century she-wolf gravestones (stelae, altars and ash-chests) were also carved in Gallia Cisalpina, which at that time was already fully Romanized. Soon afterwards the motif began to appear in the provinces of Noricum and Pannonia, where it remained in use until the middle of the $2^{\text {nd }}$ century. ${ }^{82}$ From the middle of the $2^{\text {nd }}$ until the middle of the $3^{\text {rd }}$ century the motif appeared further eastwards on the gravestones of Dacia. ${ }^{83}$ The she-wolf was among the most popular mythological motifs on provincial Roman gravestones. It was usually the only mythological element on them, sometimes accompanied by other purely decorative motifs ${ }^{84}$

The geographical distribution of the she-wolf gravestones is worth noting (see Fig. 13). All the 41 stelae found outside of Italy are from the Danubian provinces (see Table 1 below). Some of the Pannonian gravestones reveal a strong Italian influence, which indicates that this figurative motif came to Pannonia from northern Italy (Gallia Cisalpina) in the late $1^{\text {st }}$ century. The turn of the $1^{\text {st }}$ and $2^{\text {nd }}$ century was a period of intense Romanization along the Amber Road ${ }^{85}$ and in the southern parts of Pannonia and Noricum. At the same time the she-wolf, along with other motifs of Greco-Roman mythology, began to appear on Pannonian gravestones ${ }^{86}$ The long time span (from the late $1^{\text {st }}$ to the $3^{\text {rd }}$ century CE) and the diffuse provenance suggest that gravestones with a she-wolf relief did not come from any particular center but were carved independently in several different locations. ${ }^{87}$

Reliefs with the she-wolf motif have also been found on some large-sized funerary monuments, aediculae and sarcophagi. These cases are fewer and geographically more dispersed than those of the gravestones, but they too are concentrated on the northern borders of the Empire (cf. Figs 3 and 13). There are seven known examples of the she-wolf motif on funerary monuments: one is from Belgica (Orolaunum), ${ }^{88}$ three from Germania (Inferior:

\footnotetext{
${ }^{78}$ AichHOLZeR 1983, 92-93; Weigel 1992, 292-296.

${ }^{79}$ Arheološki muzej Zadar, inv. no. A10202. GIUNIO 2005, 220-221; DARDENAY 2012, 307-308, n. L249.

${ }^{80}$ DuLIÈRE 1979, II, 150-162, 164-166, 169-170, 176 177, 180-183, 186 bis-193; DARDENAY 2012, 298-302, n. L214-L234.

${ }^{81}$ DULIÈRE 1979, II, G1-G30; AichHOLZER 1983, Kat. 300333; DARDENAY 2012, 245-250, n. L4-L14; 267-269, n. L90-L105.

${ }^{82}$ SCHOBER 1923, 163-164; A. BiJKer: The lupa Romana in the decorations of Roman grave monuments. In: H. J. Waterbolk (ed.): Caeculus. I: Images of Ancient Latin Culture. Groeningen 1992, 118-120; CADARIO 2001, 151-160.

${ }^{83}$ PoP 1971, 173-185; L. BIANCHI: Ancora sulla lupa di Apulum: aspetti del provincialismo Dacico. ArchClass 28 (1976) 161-168; M. BĂRBULESCU: Signum originis. In: M. Bărbulescu (ed.): Funeraria dacoromana. Arheologia funerara a Daciei romane. ClujNapoca 2003, 164-169.

${ }^{84}$ SCHOber 1923, 164-174; SChaUenbuRg 1966, 262.

${ }^{85}$ Running north from the Adriatic Sea via Poetovio, Savaria and Scarbantia in western Pannonia.
}

${ }^{86}$ ERDÉLYI 1950, 72-82; M. VERZÁR BASS: Arte funeraria lungo la via dell'ambra. In: M. Buora (ed.): Lungo la via dell'Ambra. Apporti altoadriatici alla romanizzazione die territori del Medio Danubio. Udine 1994, 257-265; D. GABLER: Der gesellschaftliche Hintergrund der mythologischen Darstellungen in Pannonien. In: E. Walde-B. Kainrath (Hrsg.): Die Selbstdarstellung der römischen Gesellschaft in den Provinzen im Spiegel der Steindenkmäler. Akten des IX. Internationalen Kolloquiums über Probleme des Provinzialrömischen Kunstschaffens. Ikarus 2. Innsbruck 2007, 13-26.

${ }^{87}$ ERdÉlyi (1950, 75-79) and SZIRMAI (1989-90; $163-$ 164) suggest that the center of production of lupa gravestones was first in Poetovio, whence the influence spread eastwards, along the river Drava. In the light of the geographical distribution and the dating of the extant gravestones this theory is possible.

${ }^{88}$ Musée National d'Histoire et d'Art, Luxembourg, inv. Lap. 3. Cf. E. Wilhelm: Pierres sculptées et inscriptions de l'époque Romaine. Luxembourg 1974, n. 284. Orolaunum is modern Arlon in Belgium. 


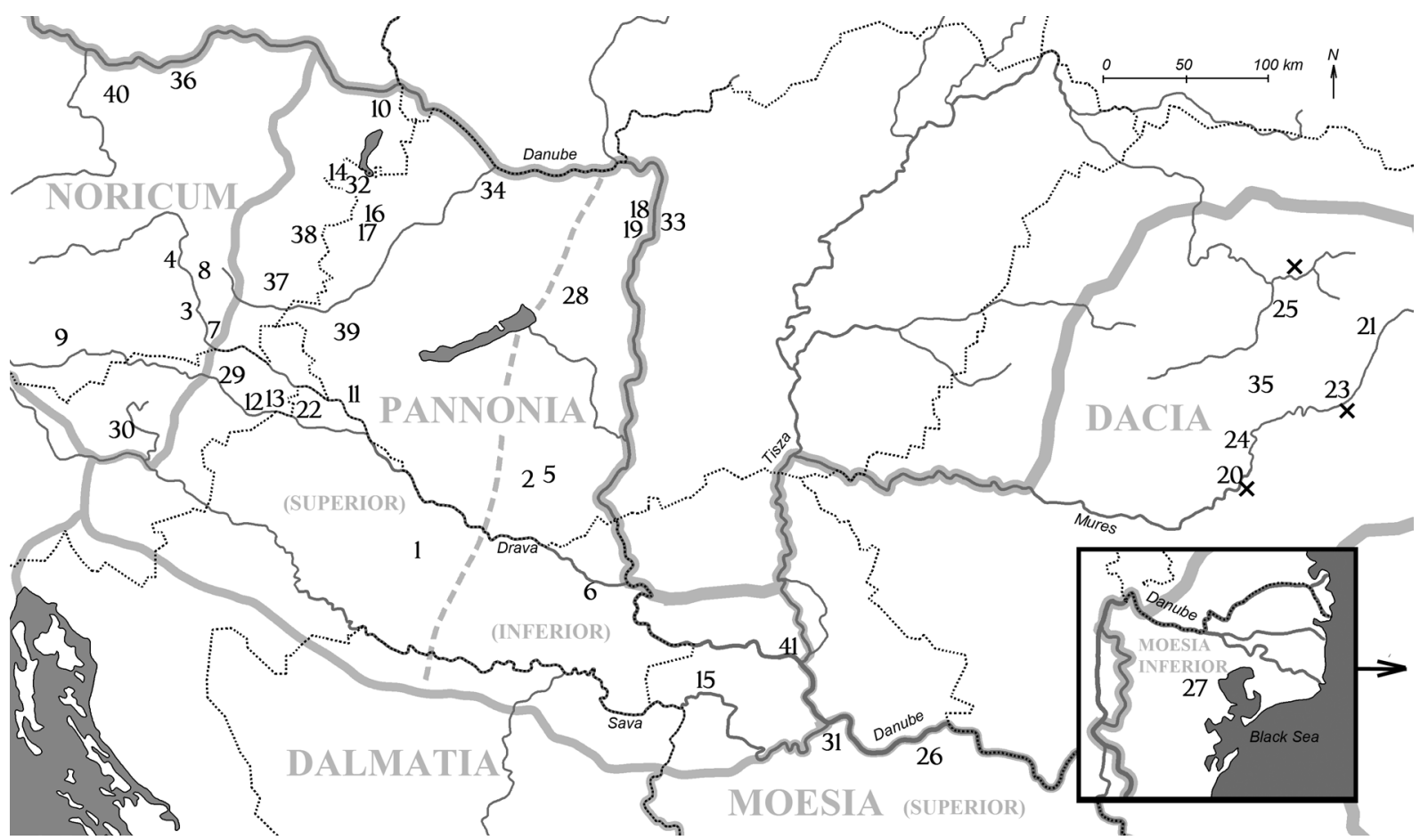

Fig.13. Map of gravestones with the she-wolf motif in the Danubian provinces (numbers referring to Table 1). Other she-wolf reliefs in a funerary context are marked with X. Drawn by the author

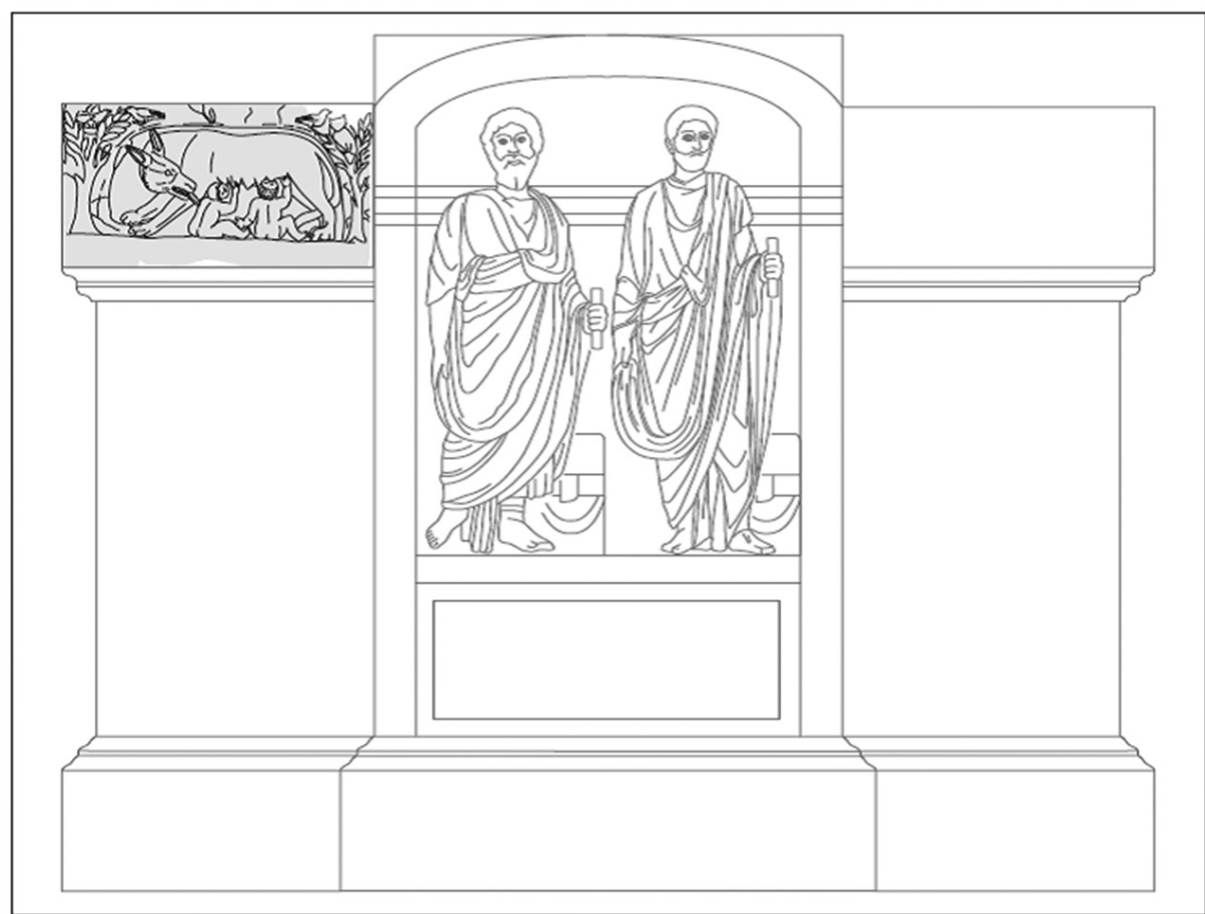

Fig. 14. (LEFT) Reconstruction of the honorary monument of Aventicum.

End of the $2^{\text {nd }}$ century or beginning of the $3^{\text {rd }}$ century CE. Photo source: MoRel 2010, 130, Abb. 114

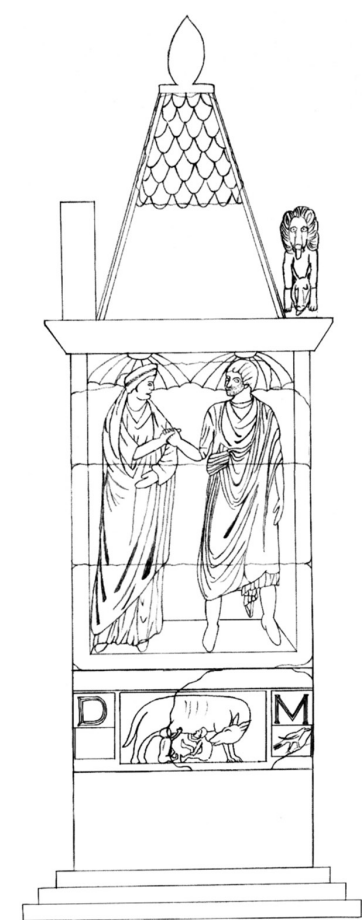

Fig. 15. (RIGHT) Reconstruction of the Oberstaufenbach funerary monument. First half of the $2^{\text {nd }}$ century CE. Photo source: DiTsCH 2011, Taf. 35 


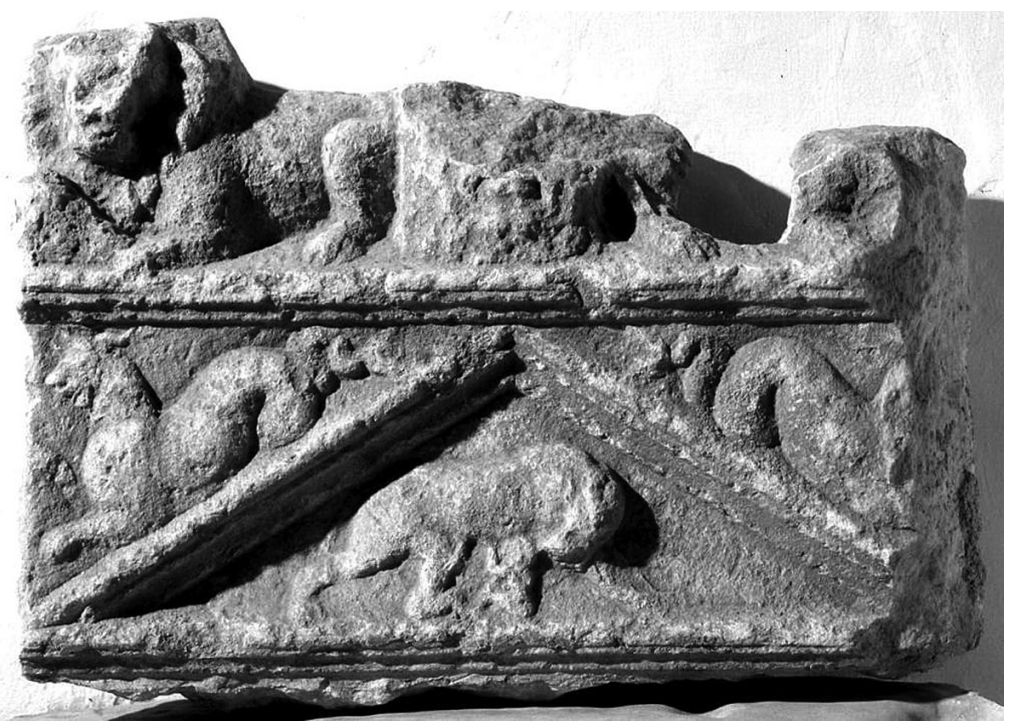

Fig. 16. (LEFT) Gravestone from Poetovio, Pannonia Superior (no. 12).

$2^{\text {nd }}$ century CE. Photo source: Regional Museum Ptuj-Ormož. Photo: B. Farič

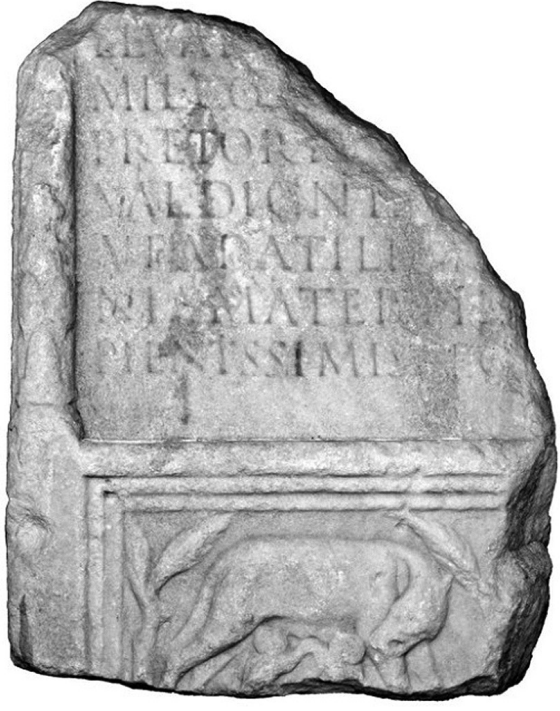

Fig. 17. (RIGHT) Gravestone from Bastaji, Pannonia Superior (no. 1). 75-125 CE. Photo: I. Radman

Maastricht, and Superior: Vicus Murrensis and Oberstaufenbach, Fig. 15), ${ }^{89}$ one from Raetia (Castrum Celeusum), ${ }^{90}$ and two from Dacia (Apulum and Dej). ${ }^{91}$ The distinction between funerary and other kinds of monuments is not always clear. For example, the funerary monument from Oberstaufenbach (Fig. 15) has remarkable similarities with the honorary monument from Aventicum (Fig. 14) mentioned above.

The she-wolf motif also appears on two funerary aediculae mentioned above, one found in Raetia (Castra Regina) and the other in Dacia (Cristeşti). ${ }^{92}$ A sarcophagus from Gallia Narbonensis shows the image of the she-wolf and the twins along with other decoration. ${ }^{93}$

I have divided the 41 she-wolf reliefs on provincial stelae iconographically into three groups (cf. Table 1). ${ }^{94}$

I. The she-wolf with the twins is represented in an archetypical trapezoidal composition in almost eighty percent of the gravestones. This type has clear parallels in the reliefs on some gravestones from northern Italy (Piedmont) dating from the late $1^{\text {st }}$ century CE. ${ }^{95}$ Sometimes the she-wolf is accompanied by other elements of the myth,

89 1) Gemeinde Maastricht, Inv.-Nr. BM 2452A-006; KEMPCHEN 1995, 214, n. 82; T. PANHUYSEN: Romeins Maastricht en zijnbeelden. Roman Maastricht reflected in stones. CSIR Germania Inferior, Nederland, Maastricht. Assen/Maastricht 1996, 312-316, $\mathrm{n}$. 43; T. PANhuYsen: Grabmäler des 2. und 3. Jahrhunderts in Maastricht. KölnerJb 41 (2008) 716, n. 10; 2) Walterichskirche, Murrhardt; KEMPCHEN 1995, 161-162, n. 8; 215, n. 84. Vicus Murrensis is modern Murrhardt in Baden-Württemberg, Germany.

3) Historisches Museum der Pfalz Speyer, Inv. 710(6). DuLIÈRE (1979, II, 109) suggests that the block with the she-wolf motif was part of the decoration of a public building, but more probably the block, together with other blocks in the museum, belongs to a five meter high grave monument (inv. 710 a-c). Cf. Diтsch 2011, 138-142.

${ }^{90}$ Wall of Sebastiankapelle, Pförring. CSIR Deutschland I, 1. Bonn 1973, n. 509. Castrum Celeusum is modern Pförring in Bavaria, Germany.

91 1) Museum Alba Iulia, nr. inv. 232 /11; found in Apulum (modern Alba Iulia in Romania), dating from 100-200 CE; Cf. BIANCHI 1976, 161-178; 2) Muzeul Municipal Dej, inv. 11 / 88; found in Ilişua, dating from 100-300 CE; Cf. C. GAIU-R. ZăGREANU: Inscripții și piese sculpturale din castrul roman de la Ilișua. Cluj-Napoca 2011, 109.
${ }^{92}$ See above, note 47.

${ }_{93}$ The sarcophagus (Marseilles, Musée Borély, inv. n. 1674) dates from the $2^{\text {nd }}$ or $3^{\text {rd }}$ century CE, and has its models in Roman and Italian sarcophagi. SchauEnBURG 1966, 267-268; DuLIÈRE 1979, I, 287-293; II, 124-134b. Another sarcophagus kept in a provincial museum (Stuttgart, Landesmuseum Württemberg, Inv. Arch. 63/8) is probably of Italian origin.

${ }^{94}$ SzIRMAI (1989-90, 162-167) too classifies the Pannonian she-wolf gravestones into three groups which, however, differ from my classification. Szimai's southern group (nos 1, 2, 5, 6, 13 and 15 in my Table 1) includes gravestones showing direct Italian influence. The western group (my nos 10, 11, 12, 16, 22, 37 and 39) shows some local transformations, and the eastern group, which contains only one example (my no. 33), depicts the she-wolf, with strong provincial influence, as a part of a larger scene. A. DARDENAY $(2012,77)$ classifies the she-wolf motifs (both on gravestones and in other contexts) on the basis of the position of the she-wolf and the twins.

${ }^{95}$ Mercando-PACI 1998, n. 129 (Palazzo Madama, Torino), 131 (Santuario di Todocco, Torre Uzzone), 133 (Palazzo Zoja, Asti); CAdario 2001, Figs 2, 3 and 6. Cf. Dardenay 2012, 114-115. 
such as the cave of Lupercal ${ }^{96}$ and the fig tree, ficus Ruminalis. ${ }^{97}$ The relief is placed either on the tympanum above the inscription (on 9 stones; cf. Fig. 16) 98 $^{9}$ or below the text on a framed rectangular panel (on 23 stones; cf. Fig. 17).

II. The composition is rather rectangular, with the muzzle of the animal turned downwards. The execution of the relief is less refined and the style is overall more angular than in the reliefs in the first group (cf. Fig. 18). Even though some elements are similar to those on a $2^{\text {nd }}$ century gravestone from Piedmont, ${ }^{99}$ it is likely that these "rectangular" she-wolves were not copied from one particular model. ${ }^{100}$ They seem rather to represent a provincial transformation caused by local Pannonian and Dacian influence. ${ }^{101}$

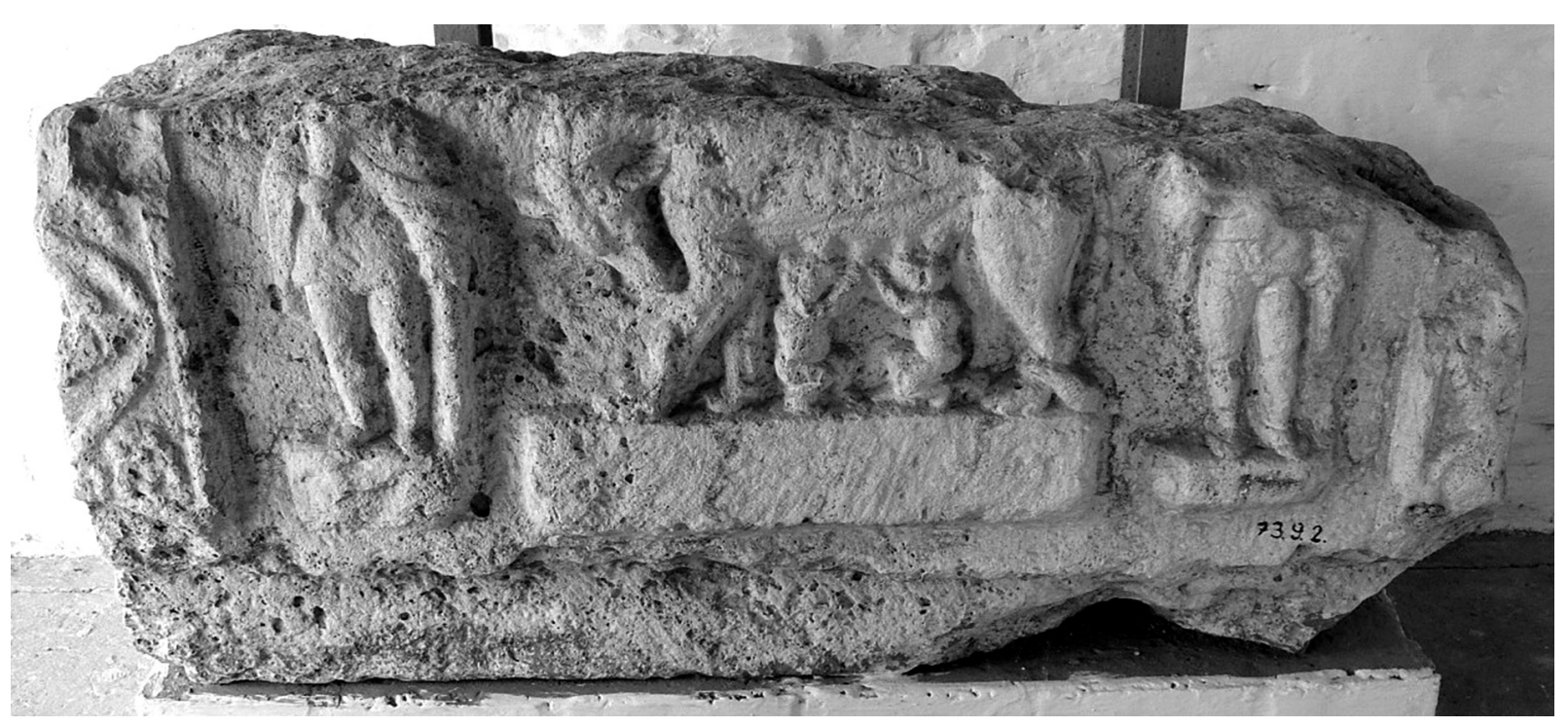

Fig. 18. Gravestone from Aquincum, Pannonia Inferior (no. 33). 150-170 CE. Photo source: Aquincum Museum

III. The body of the she-wolf is elongated, her head is turned right round, and the execution of the relief is very rough. The appearance of the animal is fierce (cf. Fig. 19). Five extant provincial gravestones can be classified in this group, two of them being from northern Noricum ${ }^{102}$ and three from different parts of Pannonia. The style differs greatly from the reliefs of the other two groups. The similarities between two images belonging to this group (nos 36 and 40 in Table 1) are remarkable, which may indicate a common origin. A remote stylistic parallel could be found in the elongated body of the she-wolf on a $1^{\text {st }}$ century CE gravestone from Piedmont, ${ }^{103}$ even though the Italian relief is far more refined than these later provincial ones.

${ }^{96} \operatorname{Nos} 5,9,13,16,21$ and 36.

${ }^{97} \operatorname{Nos} 1,2,3,8,10,14,18,29$ and 39. On the depiction of vegetation on the gravestones with the she-wolf motif, see S. PALÁGYI: Landschaftsbilder auf pannonischen Grabstelen?. In: P. Noelke (Hrsg.): Romanisation und Resistenz in Plastik, Architektur und Inschriften der Provinzen des Imperium Romanum. Akten des VII. Internationalen Colloquiums über Probleme des Provinzialrömischen Kunstschaffens, Köln, 2. bis 6. Mai 2001. Neue Funde und Forschungen. Mainz 2003, 481-488.

${ }^{98} \operatorname{Nos} 3,8,10,12,16,17,22,29$ and 30. On the stones with the tympanum (the above-mentioned 9 stones of the first group and no. 39 of the third group) there are additional figurative motifs which do not belong to the myth of the Lupa, such as imaginary animals, filling the spaces left empty by the triangular tympanum (horror vacui, cf. Figs 16, 20, 21).

${ }^{99}$ Castello di Reano, Torino. Mercando-PaCi 1998, n. 132; CADARIO 2001, 158, Fig. 5.
${ }^{100}$ Similarities between reliefs belonging to different groups can naturally be found. For example, all three gravestones found in Aquincum (nos 18, 19 and 33) present the she-wolf surrounded by shepherds. Even though they belong to different iconographic groups, the common elements in them indicate their common origin.

101 The only gravestone in Szirmai's eastern group (my no. 33 ) belongs iconographically in this group. Her geographical classification seems apt, as similar motifs have been found on two stelae from northeastern Pannonia (no. 34) and Dacia (no. 35). Two above-mentioned she-wolf reliefs of funerary art from Dacia (monument of Dej [see above note 91] and aedicula of Cristeşti [see above note 47]) can be classified iconographically as belonging in this group, too.

${ }^{102}$ Cf. V. JoBst: Römische Grabdenkmäler im Stift Melk. JÖAI 50 (1972-73) 272-280.

${ }^{103}$ Torino, Museo di Antichità, inv. 379. Mercando-PACI 1998, n. 66; CADARIO 2001, 158, Fig. 4. 


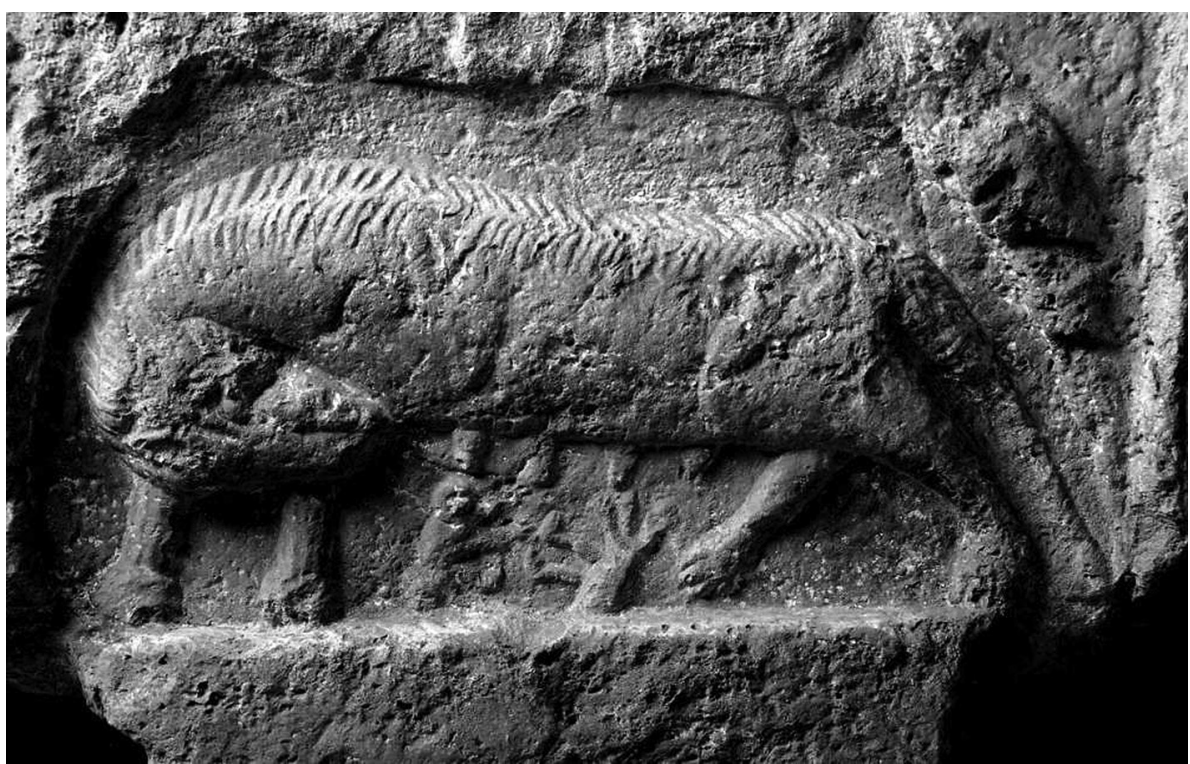

Fig. 19. Gravestone from Titel, Pannonia Inferior (no. 41). $2^{\text {nd }}$ or $3^{\text {rd }}$ century CE. Photo source: Muzeul Banatului, Timișoara

Table 1. Provincial gravestones with the she-wolf motif, classified iconographically into three groups.

\begin{abstract}
For each gravestone we list where it was found, its current location with inventory details, dating if possible, reference numbers in the listings of C. Dulière ${ }^{104}(C D)$, A. Márton ${ }^{105}(A M)$, A. Dardenay ${ }^{106}(A D)$ and the Ubi Erat Lupa database ${ }^{107}(U E L)$, possible further bibliographical references, and the direction in which the she-wolf is heading.

I

1. Bastaji, Pannonia Superior (Bjelovar-Bilogora, Croatia); Arheološki Muzej u Zagrebu, inv. AMZ KS-936; 75-125 CE; CD 89, AM 9, AD L145, UEL 3810; CIL III 4001; Right.

2. Boda, Pannonia Inferior (Baranya, Hungary); Janus Pannonius Múzeum Pécs, Inv. Nr. 1278; 75-125 CE; CD 97, AM 3, AD L146, UEL 808; CSIR U VII, 77; Right.

3. Flavia Solva, Noricum (Leibnitz, Styria, Austria); wall of Schloss Seggau; 75-125 CE; CD 83, AD L152 and AD L163b, UEL 1270; Left. 4. Frohnleiten, Noricum (Styria, Austria); southern wall of St. Georgskirche, Adriach; 75-150 CE; CD 81, AD L171; UEL 1436; CIL III 5458; Right.

5. Sopianae, Pannonia Inferior (Pécs, Baranya, Hungary); Magyar Nemzeti Múzeum Budapest, Inv. Nr. MNM, R-D 389; 100-125 CE; CD 98, AM 19, AD L178, UEL 676; CIL III 3311 = 10292; CSIR U VII, 59; Right.

6. Mursa, Pannonia Inferior (Osijek, Osijek-Baranja, Croatia); private collection; 100-125 CE; AM 8, AD L179, UEL 4296; Left.

7. Strass in Steiermark, Noricum (Styria, Austria); wall; 100-150 CE; CD 80, AD L170, UEL 1356; CIL III 5361; Right.

8. Eggersdorf bei Graz, Noricum (Styria, Austria); wall of the parish church; 100-150 CE; CD 82, AD L172, UEL 1418; CIL III 5487; Left. 9. Virunum, Noricum (Zollfeld / Maria Saal, Carinthia, Austria); wall of Marienkirche; 100-150 CE; CD 86, AD L143, UEL 1043; CSIR Ö II, 1, 333; Right.

10. Carnuntum, Pannonia Superior (Bad Deutsch-Altenburg, Lower Austria, Austria); Schloss Ludwigstorff; 100-150 CE; AD L163, UEL 1844; Right.

11. Becsehely, Pannonia Superior (Zala, Hungary); Thúry György Múzeum Nagykanizsa, Inv.-Nr. 81.217.1; 125-175 CE; AM 6, AD L159, UEL 3403; CSIR U VIII, 18; Right.

12. Poetovio, Pannonia Superior (Ptuj, Podravska, Slovenia); Pokrajinski muzej Ptuj Ormož, Inv. No. RL-96; 100-200 CE; CD 90, AM 18, AD L148, UEL 3779; Right.

13. Poetovio, Pannonia Superior (Ptuj, Podravska, Slovenia); Pokrajinski muzej Ptuj Ormož, Inv. No. RL-95; 100-200 CE; CD 91, $A M$ 17, AD L165, UEL 3772; Left.

14. Ágfalva, Pannonia Superior (Györ-Moson-Sopron, Hungary); Soproni Múzeum, inv. 2012.15.1; 100-200 CE; $A M$ 10, $A D$ L153 and $A D$ L163c, UEL 3827; Right.
\end{abstract}

${ }^{104}$ DuLIÈRE 1979, II.

${ }^{105}$ A. MÁrTON: A lupa Capitolina újabb ábrázolása Aquincumból (Eine neue Darstellung der lupa Capitolina aus Aquincum). ArchÉrt 127 (2002) 142-144.

\footnotetext{
${ }^{106}$ DARDENAY 2012

${ }^{107} \mathrm{http}: / /$ www.ubi-erat-lupa.org
} 
Table 1. Continued

15. Sirmium, Pannonia Inferior (Sremska Mitrovica, Srem, Serbia); 100-200 CE; Arheološki Muzej u Zagrebu, inv. AMZ KS-383; CD 88, AD L174; CIL III 3242; Right.

16. Chernelházadamonya, Pannonia Superior (Vas, Hungary); Savaria Múzeum Szombathely, inv. 83.2.1; 125-200 CE; AM 11, AD L156,

UEL 3824; AE 1988, 935; Right.

17. Répceszentgyörgy, Pannonia Superior (Vas, Hungary); 125-200 CE; wall of Vassurány church; UEL 3342; CIL III 10922 = 4198; RIU 1, 157; Тóth 2011, 219-221 n. 188; Left.

18. Aquincum, Pannonia Inferior (Budapest, Hungary); 150-200 CE; Aquincumi Múzeum, inv. 2012.2.10; AM 1, AD L157, UEL 10596;

A. R. FACSÁDY, BudRég 33 (1999) 279-290; Left.

19. Aquincum, Pannonia Inferior (Budapest, Hungary); 150-200 CE; Aquincumi Múzeum, inv. 2000.15.1; AM 2, AD L158, UEL 10569; Left.

20. Apulum, Dacia (Partoș / Alba Iulia, Alba, Romania); Museum Alba Iulia, nr. inv. R 7855; 150-225 CE; C. L. BĂLUŢĂ, Apulum 25 (1988) 253-254, Pl. IV,3; Right.

21. Brâncoveneşti, Dacia (Mureș, Romania); Muzeul Judeţean Mureş, inv. 6569; 150-250 CE; M. Bărbulescu, Funeraria Dacoromana. Cluj-Napoca 2003, 164-169; Right.

22. Čakovec, Pannonia Superior (Međimurje, Croatia); Muzej Međimurja Čakovec, inv. MMČ-595; $100-300$ CE; $C D$ 92, $A M 12, A D$ L147, UEL 3786; CIL III 4116; Right.

23. Cristești, Dacia (Mures, Romania); lost; 100-300 CE; CD 103, AD L151; C. PoP 1971, n. 2; Right.

24. Brucla, Dacia (Aiud, Alba, Romania); wall of Sâncrai church, Aiud; 100-300 CE; CD 99a, AD L154; Left.

25. Gherla, Dacia (Cluj, Romania); wall; 100-300 CE; C. PoP: In memoriam Constantini Daicoviciu. 1974, 311-314; Right.

26. Viminacium, Moesia Superior (Kostolac, Braničevo, Serbia); Narodni muzej Požarevac, inv. C-12736; 200-250 CE; AD L163d, UEL 5431; Right.

27. Ibida, Moesia Inferior / Scythia Minor (Slava Rusă, Tulcea, Romania); Muzeul de istorie naţională şi arheologie Constanţa, inv. nr. 6482; 275-325 CE; CD 105, AD L169, UEL 15210; Right.

28. Gorsium, Pannonia Inferior (Tác, Fejér, Hungary); Gorsium Szabadtéri Múzeum - Régészeti Park Tác, Inv. 99.3 .1 ; UEL 10083; RIU 6 Nr. 1549 b; Right.

29. Pernica pri Mariboru, Pannonia Superior (Podravska, Slovenia); in the wall of Sv. Marjeta ob Pesnici church, Pernica; UEL 12786; Right.

30. Gomilsko, Noricum (Savinjska, Slovenia); in the wall of Sveti Matevž church , Šmatevž; CD 87, AD L173, UEL 4138; CIL III 5114;

Österreichische Nationalbibliothek, CVP Nr. 3540 and 3528; Left.

31. Singidunum, Moesia Superior (Belgrade; Serbia); lost; Inscriptions de la Mésie Supérieure I, 62-63 n. 32; Left.

32. Sopron, Pannonia Superior (Győr-Moson-Sopron, Hungary); lost; CD 93, AM 14, AD L175, UEL 3360; CIL III 4248; CSIR U II, N. 66, 54; British Library Add MS 15771, folio 13; Right.

II

33. Aquincum, Pannonia Inferior (Budapest, Hungary); Aquincumi Múzeum, inv. 73.9.2; 150-170 CE; AM 5, AD L160, UEL 3030; Left. 34. Arrabona, Pannonia Superior (Bacsa / Győr, Győr-Moson-Sopron, Hungary); Xántus János Múzeum Győr, inv. 57.1.10; 150-225 CE; UEL 3081; CIL III 13441; CSIR U II, 95; Right.

35. Potaissa, Dacia (Turda, Cluj, Romania); unknown; Téglás István jegyzetei - Régészeti feljegyzések I/2, 543 n. 1912; Right.

III

36. Pöchlarn, Noricum (Lower Austria, Austria); wall of the garden at Stift Melk; 75-125 CE; CD 85, AD L167b,UEL 357; CSIR Ö I,6, 25; Right.

37. Rax / Jennersdorf, Pannonia Superior (Burgenland, Austria); Savaria Múzeum Szombathely, Inv.-Nr. 67.10.74; 100-125 CE; CD 94, AM 16, AD L176, UEL 453; CIL III 10895; CSIR Ö I,5, 13; Right.

38. Stadtschlaining, Pannonia Superior (Burgenland, Austria); lost; 100-150 CE; CD 95, AM 13, AD L177, UEL 469; CIL III 4212;

W. KuBitscheK, Jahrbuch für Altertumskunde 6 (1912) 141 Fig. 34; Right.

39. Salla, Pannonia Superior (Zalalövő, Zala, Hungary); Göcseji Museum Zalaegerszeg, Inv.Nr. GM, 50.4.1; 100-150 CE; $C D$ 96, $A M$ 15, AD L149, UEL 3401; CSIR U VIII, 13; Left.

40. Aschbach, Noricum (Lower Austria, Austria); Archäologische Sammlung, Stift Seitenstetten; 75-200 CE; CD 84, AD L150, UEL 478; CSIR Ö III,2, 34A; Right.

41. Titel, Pannonia Inferior (South Bačka, Serbia); Muzeul Banatului, Timișoara, inv. IV 6349; 100-300 CE; CD 100, AD L180, UEL 17547; Left. 
It should be noted that the she-wolf motif appears on gravestones in Italy and all around the Danubian provinces, but not elsewhere in the Roman Empire. ${ }^{108}$ It is found on funerary monuments and aediculae in the northwestern provinces too. ${ }^{109}$

The geographical concentration of the stelae cannot be explained as the result of administrative control. Even if the authorities could control the use of symbolically significant images in public use, such as on coins and on imperial cuirasses, in the private sphere, such as on gravestones, individuals were free to choose the pictorial motifs they used.

The frequency of the motif may be at least partly a question of imitation, as the models from northern Italy were naturally followed first in southern Noricum and Pannonia and later all over the Danubian provinces. However, it must be noted that the she-wolf was never an ordinary funerary motif, not even in Pannonia and Noricum. The Lupa Romana could have been used on gravestones to emphasize the special status of those who had erected the stone. In my opinion, one of the reasons for the concentration of the Lupa gravestones along the Danube is the lower level of civilization of the Danubian provinces. The literacy rate was low in these provinces, but even the illiterate could interpret visual symbols. ${ }^{110}$ The she-wolf with the twins was an unequivocal symbol of the Roman Empire.

The she-wolf gravestones are not concentrated in any particular center or centers in the Danubian provinces. They appear most densely in western Pannonia, in the area of the Amber Road. This, however, does not differ from the general distribution of $1^{\text {st }}$ and $2^{\text {nd }}$ century gravestones. ${ }^{111}$ There does not seem to be any political explanation for the distribution of the she-wolf gravestones, even though P. Barocelli suggests that they indicate the Roman origin of the settlement. ${ }^{12}$ His theory can be rejected, as only five of the 41 gravestones originated in a colony, ${ }^{113}$ thirteen in a municipium, ${ }^{114}$ and five in a fortress. ${ }^{115}$ Thus almost half of them seem to have no direct connection with a Roman settlement. Four were found in smaller towns with no claims to municipal status, ${ }^{116}$ and fourteen in locations with no known settlement nearby. ${ }^{117}$ The maximum number of she-wolf gravestones found in any one settlement is three, namely in Aquincum (Budapest). ${ }^{118}$ The presumed dating of these gravestones (150-200 CE) does not coincide with the raised administrative status of their towns of provenance, as did the minting of the shewolf coins in Asia Minor. Even though the she-wolf reliefs from the colonies of Poetovio and Mursa, and from the municipia of Salla and Carnuntum are roughly contemporary with administrative changes, ${ }^{119}$ in some other towns,

${ }^{108}$ The geographical distribution, for example, of funerary lions in Roman provincial art is much more regular, although still far from uniform. F. HuNTER: Funerary lions in Roman provincial art. In: P. Noelke (Hrsg.): Romanisation und Resistenz in Plastik, Architektur und Inschriften der Provinzen des Imperium Romanum. Akten des VII. Internationalen Colloquiums über Probleme des Provinzialrömischen Kunstschaffens, Köln, 2. bis 6. Mai 2001. Neue Funde und Forschungen. Mainz am Rhein 2003, 61.

${ }^{109} \mathrm{Cf}$. chapter "Gravestones and funerary monuments" above. Their distribution along the northern border (Belgica, Germania, Raetia and Dacia) could be explained by the presence of many Roman legions and the need to emphasize romanitas along the border of the Empire.

${ }^{110}$ Mócsy 1974, 262 - 263; W. V. HARRIS: Ancient Literacy. Cambridge 1989, 183-184, 268-269. Cf. G. AlFöLdy: La Pannonia e 1'Impero Romano. Rivista Storica dell'Antichità 41 (2011) 163-165.

${ }^{111}$ Cf. Mócsy 1974, 232-233, Fig. 38.

112 P. Barocelli: Notizie degli scavi di Antichità. 1. Atti della Reale Accademia Nazionale dei Lincei. Ser. 6. Roma 1925, 97-98.

${ }^{113}$ Four in Pannonia (nos 6, 12, 13 and 15) and one in Moesia Superior (no. 31).

${ }^{114}$ Four in Noricum (nos 3, 7, 9 and 30), seven in Pannonia (nos 10, 14, 18, 19, 32, 33 and 39), one in Moesia Superior (no. 26) and one in Dacia (no. 35). Nos 7 (Strass), 14 (Ágfalva), 30 (Gomilsko) and 32 (near Sopron) very probably have their origin in the nearby municipia of Flavia Solva, Scarbantia and Celeia. On the other hand,
DuLIÈRE (1979, II, 80-82) suggests that all four of the gravestones found in Styria (nos 3, 4, 7 and 8) were originally from Flavia Solva, which is, however, over 60 kilometres away from Frohnleiten (no. 4).

115 One in Noricum (no. 36), two in Pannonia (nos 34 and 41), one in Dacia (no. 20) and one in Moesia Inferior / Scythia Minor (no. 27).

116 Three in Pannonia (nos 2, 5, and 28) and one in Dacia (no. 24). No. 2 (Boda) very probably comes from Sopianae.

${ }^{117}$ Three in Noricum (nos 4, 8 and 40), eight in Pannonia (nos 1, 11, 16, 17, 22, 29, 37 and 38) and three in Dacia (nos 21, 23 and 25). Most of them are located along the route of Roman roads. Only gravestones nos 1 (from Bastaji) and 38 (from Stadtschlaining) were found in locations remote from a Roman road.

${ }_{118}$ Nos 18, 19 and 33. Two gravestones were found in Poetovio (nos 12 and 13), two in close vicinity to Flavia Solva (nos 3 and 7), two in Scarbantia (nos 14 and 32) and two in Sopianae (nos 2 and 5). The gravestones of Chernelházadamonya (no. 16) and Répceszentgyörgy (no. 17) were found less than a kilometer from each other.

${ }^{119}$ Poetovio was established as a colony in $103 \mathrm{CE}$; the dating of the gravestones (nos 12 and 13) is 100-200 CE. Mursa got colonial status (Colonia Aelia Mursa) during Hadrian's reign, in 117$138 \mathrm{CE}$; the gravestone (no. 6) dates from 100-125 CE. Municipium Aelium Salla was first mentioned in 128, and was presumably founded in the first decade of Hadrian's reign, in 117-128 CE; the gravestone (no. 39) is dated 100-150 CE. Carnuntum got municipal status in 124 $\mathrm{CE}$; the gravestone (no. 10) dates from 100-150 CE. 
such as Virunum, Sirmium, Viminacium and Aquincum, no connection of this kind can be found. ${ }^{120}$ The remaining examples appear to be quite fortuitous too.

It can be argued that the she-wolf, with its well-known symbolism, was not selected at random from the pattern-books of the stonemasons' workshops, ${ }^{121}$ but expressed the relationship that the owner of the tomb had with the Roman Empire. ${ }^{122}$ In some cases this connection seems to have been citizenship, in others a career in the Roman army, or the Italian origin of the family. However, a definite biographical factor cannot be found in every case. ${ }^{123}$ The majority of the gravestones that have been found with the she-wolf motif have been nameless, but those with names reveal that many of the people mentioned did indeed have a special reason to emphasize their romanitas.

One of the reasons may be that many of the people mentioned in the inscriptions were of provincial origin, and they wanted to enhance their social standing. For example, the names of Nammus Cabalionis filius (no. 8), Solia Loturi filia (no. 8) ${ }^{124}$ and Litugena Atti filia (no. 14) ${ }^{125}$ indicate their Celtic origin. ${ }^{126}$ On the other hand, the names of Finitus Lappi filius and Salvia Iantumari filia (no. 7) ${ }^{127}$ give a clear example of the Romanization of Noricum in the first half of the $2^{\text {nd }}$ century. Fathers with Celtic names (Lappus, Iantumarus) gave their children Roman names, ${ }^{128}$ perhaps in an attempt to improve their prospects as members of their community. The name formula shows clearly that the individuals concerned were not Roman citizens.

Secondly, some people in the provinces definitely had Roman citizenship, such as Ulpius Pirus and his wife Ulpia Ruca (no. 5), who besides their own names had the gentilicium Ulpius as a mark of Roman citizenship. ${ }^{129}$ The same applies to Marcus Ulpius Firminus (no. 30) ${ }^{130}$ and the magistrates Titus Baebius Eutyches (no. 26, augustalis municipii; the augustales were freedmen) ${ }^{131}$ and Gaius Iulius Florus (no. 15, decurio coloniae; marked as freeborn by his filiation $C$.f.). ${ }^{132}$ Their use of the she-wolf motif would be a sign of their belonging.

Thirdly, some men can be identified as soldiers of the Roman army (nos 1, 27, 32 and 34), which makes the use of the she-wolf motif understandable - especially in the case of Valerius Valens (no. 27), ${ }^{133}$ a soldier in the

${ }^{120}$ Virunum became a municipium in 41-54 CE; the dating of the gravestone (no. 9) is 100-150 CE. The colony of Sirmium was founded in 69-79 CE; the gravestone (no. 15) dates from 100-200 CE. Viminacium became a municipium in 117; the gravestone (no. 26) dates from 200-250 CE; Viminacium was raised to a colony in 239 $\mathrm{CE}$, which would be contemporary with the gravestone, but the deceased was an augustalis municipii, as will be noted below. Aquincum got its municipal status in 117-138 CE; the gravestones (nos 18, 19 and 33) date from 150-175/200 CE.

${ }^{121}$ Suggested in Mócsy 1974, 262 (with reservations).

${ }^{122}$ SCHAUENBURG 1966, 306-309; DuliÈre 1979, I, 285-287.

${ }^{123}$ For example, there is no evidence to support the suggestion of H. I. MARROU (Deux sarcophages romains relatifs à la vie intellectuelle. RA ser. VI 1 [1933] 170) that the deceased had lived in Rome.

${ }^{124}$ CIL III 5487: Nammo / Cabalionis / f(ilio) an(norum) LX et / Soliae Loturi / f(iliae) an(norum) XXXX.

${ }^{125}$ Li[t] ugena At/t[i] f(ilia) v(iva) $f($ ecit $)$ si $\{i\}$ bi et / Iul[io] Secundi/[no] $f($ ilio $)$ an $[n($ orum $)$--- et $] \operatorname{Vib}[e] / n($ a)e vernac $(u)($ lae $)$ an(norum) [---].

${ }^{126}$ A. MócsY: Der Grabstein einer romanisierten Keltischen Familie in der Umgebung von Scarbantia. ActaArchHung 40 (1988) 101-110; X. Delamarre: Dictionnaire de la langue Gauloise. Paris 2001, 173 s.v. litu-; 243 s.v. suli- / soli-; DelamarRe 2007, 118 s.v. Litugenus, -ius, - $a$; 138 s.v. Nammus; 171 s.v. Sollus, -ius, -ia, -o;

${ }^{127}$ CIL III 5361: Finito Lappi (filio) / an(norum) LX et / Salviae / Iantumari f(iliae) / con(iugi) opt(imae) fil(ii) / fecerunt.

${ }^{128}$ Delamarre 2007, 107 s.v. Iantumarus, - $a$; 115 s.v. Lappus. Cf. Non-Mediterranean Names in Noricum (NNN) -database. [http://www.univie.ac.at/austria-celtica/personalnames/]

${ }^{129}$ CIL III 3311: ---]ae an(n)os XXV Ulp(ius) / Pirus pate(r) v(ixit) an(nos) XL p(osuit) / Ulp(ia) Ruca mater fili(i)s / dul(cissimis) (h)ereseorum. D. PINTERović (Nepoznati rimski natpisi iz Osijeka [Three unknown Roman inscriptions from Mursa]. Osječki Zbornik 16 [1977] 91-97) suggests that Felix (no. 6) also had Roman citizenship because he had a Roman cognomen, but in my opinion that cannot be regarded as proof of citizenship. Felix was a name commonly given by the Romans to slaves (I. KAJANTO: The Latin Cognomina. Helsinki 1965, 73 and 273).

${ }^{130}$ CIL III 5114: Ulpia Firmin(a) an(n)orum triginta / M(arcus) Ulpius / Firminus et / Connonia Statuta / v(ivi) fecerunt / sibi et Ulpio Primiano / f(ilio) an(norum) XIII.

${ }^{131} D($ is ) M(anibus) / T(ito) Baeb(io) Eutychi / aug(ustalis) mun(icipii) Ael(ii) Vim(inacii) / qui v(ixit) a(nnos) LXV et / Baebiae Marcel/lae eius / T(itus) Baeb(ius) Abascan/tus aug(ustalis) eiusdem / mun(icipii) patronis. B. Milovanović-N. MrĐić: The she-wolf motif with Romulus and Remus on a tomb stela of an Augustal from Viminacium. Bollettino di Archeologia On Line 1 (2010) (XVII International Congress of Classical Archaeology, Roma 22-26 Sept. 2008, Session: Death and Religion in Classical Antiquity / Aspetti Culturali e Funerari nell'Antichità Classica) 90-94.

${ }^{132}$ CIL III 3242: ---] / Civilis / dec(urio) col(oniae) ann(orum) L / et C(aius) Iul(ius) C(ai) f(ilius) / Florus dec(urio) col(oniae) / ann(orum) XX et Iuliae / Festae ann(orum) XII / Anicia Macrina / marito et fil [is]. V. DAUTOVA-RUŠEVLJAN: Rimska kamena plastika u jugoslovenskom delu provincije Donje Panonije. Novi Sad 1983, 15 n. 29.

$\left.{ }^{133} \mathrm{AE} 1977,756:---\right] /[---] R(?)$ se vivi(?) [--- $] A(?) /[-V]$ al(erius) Valens mile/[s l(egionis)] XI Cla(udiae) mil(itavit) ann/[os] III vix(it) ann (os) XXII / [fil]io b(ene) m(erenti) p(osuerunt). Z. CovACEF: Sculptura antică din expoziţia de bază a Muzeului de Istorie Naţională şi Arheologie Constanţa (Ancient Sculpture in the Permanent Exhibition of the Museum of National History and Archaeology Constanţa). Cluj-Napoca 2011, 212 nr. 98. 
Legio XI Claudia, which had the she-wolf as its emblem, as mentioned above. ${ }^{134}$ Flavius Valerius had served as a miles cohortis praetoriae (no. 1) $)^{135}$ and his brother Valerius Dign(us?) most probably was a veteran. Aurelius Saturnio, who came from Siscia (modern Sisak in Croatia) was a librarius equeti alae, and his countryman Lucilius Vindex had the same position (no. 34). ${ }^{136}$ Gravestone no. 32 was erected by or to a militum tribunus whose name has not been preserved. ${ }^{137}$

Fourthly, two family names indicate Italian descent. According to A. Mócsy, the family of Lucius Torius Quintus (no. 38) had migrated from northern Italy, but his wife Flavia Valentina was supposedly a native Pannonian. ${ }^{138}$ The epitaphs of the family of Caesii, who came from Aquileia, ${ }^{139}$ give a unique example of the use of the Lupa motif within a family. It is obvious that Lucius Caesius Tuendus (no. 16) and Gaius Caesius Victor (no. 17) were brothers. ${ }^{140}$ The gravestone of Lucius was erected by Gaius and his three children (Fig. 20), while Gaius' gravestone was erected by his children (Fig. 21). Although Lucius died first, ${ }^{141}$ the gravestones could have been carved at the same time, with the ages of the deceased (or the whole inscription) to be filled later, as was quite common in Roman funerary culture. The stones are very similar, and they were presumably made in the same workshop. ${ }^{142}$ It seems probable that the image of the she-wolf emphasized the Italian origin of the Caesius family.

Some of those who had the she-wolf motif on their gravestones were unquestionably Roman citizens, as shown above, but contrary to what A. Sz. Burger maintains, ${ }^{143}$ there is no proof of this connection with Rome in every case. In 212 CE the Edict of Caracalla granted Roman citizenship to all free men in the Roman Empire. The she-wolf motif continued to be used on gravestones after the edict was issued, which contradicts the theory that it expressed exclusively the privileged position of a citizen. In fact, the gravestone of a Roman slave called Mystus, who definitely was not a citizen, was decorated with the she-wolf motif. ${ }^{144}$

To conclude, the Lupa Romana seems to have been known as a symbol of Rome in the Danubian provinces. The choice of the she-wolf motif can be seen as an expression of the romanitas of the deceased or his family, which could have been for several different reasons: citizenship, profession, family origin, or a person's self-identification as a Roman.

With the Roman imperial coinage the she-wolf became associated with the eternity (aeternitas) of Rome, as shown above. The idea of eternity and, consequently, of immortality, was ideal for funerary symbolism, too, and it could have had an effect on the use of the Lupa motif in the funerary context. ${ }^{145}$

${ }^{134}$ Cf. chapter "Roman coinage". The Legio XI Claudia was settled in Moesia Inferior from $104 \mathrm{CE}$ until the $5^{\text {th }}$ century. In addition to this gravestone, the only artifact with the she-wolf motif found in the region is a gem dating from the $1^{\text {st }}$ or $2^{\text {nd }}$ century $\mathrm{CE}$, which was probably made in Aquileia (Institutul de Cercetari Eco-Muzeale Tulcea, inv. 47244). M. Iacob-D. Paraschiv-G. Nutu: Romanii în Pontul stâng întimpul principatului. Catalogul expozitiei (The Romans in the Left Pontus during the Principate. Exhibition catalogue). Biblioteca istropontica. Seria patrionium 7. Tulcea 2012, 230 n. 315.

${ }^{135}$ CIL III 4001: Fl(avio) Val(erio) / mil(iti) coh(ortis) [ --- ] / pr(a)etor(iae) [ --- ] et / Val(erio) Dign[--- ] / vet(erano?) Adatili[a] A[---]/nia mater fil(iis) / pientissimis fec(it).

${ }^{136}$ CIL III 13441: D(is) M(anibus) / Aur(elio) Saturnioni / libr(ario) eq(uiti) alae / cont(ariorum) stip(endiorum) XV / an(norum) XXXV domo / Sisciae Luc(ilius) / Vindex libr(arius) / alae ei $\{i\}$ usdem / cives et heres $f$ (aciendum) c(uravit).

${ }^{137}$ CIL III 4248: ---] / mil(itum) tribunus [?

${ }^{138}$ CIL III 4212: L(ucio) Torio / Quinto / an(norum) LXX / (F)lavia Valentina / v(iva) f(ecit) sibi et con(iugi). A. Mócsy: Die Bevölkerung von Pannonien bis zu den Markomannenkriegen. Budapest 1959, 222, n. $98,3$.

${ }^{139}$ On the origin of the family, see M. MEdGYEs: Grabstein der Familie Caesius und ein spätrömisches Grab aus Chernelházadamonya. Savaria 15 (1981) 202; A. Mócsy (ed.): Nomenclator provinciarum Europae Latinarum et Galliae Cisalpinae. DissPann III.1. Budapest 1983, 59 s.v. Caesius.
${ }^{140}$ AE 1988, 935: L(ucio) Caesio C(ai) fil(io) / Tuendo an(norum) L et / Petroniae Q(uinti) fil(iae) / Crispinae coniu(gi) / an(norum) VL C(aius) Caesius C(ai) f(ilius) / Victor an(norum) fratri / piissimo C(aius) Caesius C(ai) f(ilius) / Vitulus an(norum) L(ucius) Caesius / C(ai) f(ilius) Optatus an(norum) et Caesia / C(ai) f(ilia) Graeca an(norum) nepot(es)/ avonculo; CIL III 4198 = 10922: C(aio) Caesio C(ai) / f(ilio) Cl(audia) (tribu) Victori / an(norum) LXX et Iuliae / Ti(beri) f(iliae) Proculae con(iugi) / an(norum) L C(aius) Caesius V[i]/ tulus et C(aius) Caesius Op/tatus et Caesia Grae/ca parentibus op/timis.

${ }^{141}$ M. SCHÄTZSCHOCK: Die beiden Grabsteine des Caius Caesius Victor. In: E. Walde-B. Kainrath (Hrsg.): Die Selbstdarstellung der römischen Gesellschaft in den Provinzen im Spiegel der Steindenkmäler. Akten des IX. Internationalen Kolloquium über Probleme des provinzialrömischen Kunstschaffens. Ikarus 2. Innsbruck 2005, 401-403.

${ }^{142}$ Tóth 2011, 219-223, n. 188, 189.
${ }^{143}$ Burger 1964, 54.

${ }^{144}$ CIL VI 22811: Diis ma(nibus) / Mysti L(uci) Volusi / Saturnini ser(vi) / Volusia Irene et / Dorio filio/ vixit an(nos) XV m(enses) VI / permissu $q($ ?) $n($ ?). Mystus, who was a slave of a former consul, L. Volusius Saturninus, died at the age of 15 years in $56 \mathrm{CE}$. The she-wolf motif also appears on the gravestones of two members of the family of Volusii. W. Altmann: Die römischen Grabaltäre der Kaiserzeit. Berlin 1905, 50-51 n. 2-4; SchAuENBURG 1966, 289.

${ }^{145}$ SCHAUENBURG 1966, 307. 


\section{AFTERMATH}

A brief look at later periods shows that the she-wolf remained a strong symbol, even if it developed new meanings. After the fall of the western part of the Roman Empire, the Germanic tribes identified themselves with the Roman tradition, in both Italy and other parts of the former Empire. In this context the she-wolf motif was used as a symbol of continuity between ancient Rome and the new kingdoms. In medieval Christian art, the she-wolf lost its pagan connotation. It symbolized Rome, and consequently the Christian church itself. ${ }^{146}$ On some Anglo-Saxon coins of the $8^{\text {th }}$ and $9^{\text {th }}$ century CE (see Fig. 22.c), the she-wolf motif (which was copied from the coins of Constantine the Great, Fig. 22.a) represented Rome as the original home of the church. The image might have had a political connotation too, possibly inspired by the concurrent Carolingian renaissance, proclaiming continuity and the dynasties' authority to rule. ${ }^{147}$ In the Franks Casket, an Anglo-Saxon chest made of whale bone dating from the early $8^{\text {th }}$ century, the legend of Romulus and Remus was depicted as a part of universal history, accompanied by scenes of biblical stories and Germanic legends. ${ }^{148}$

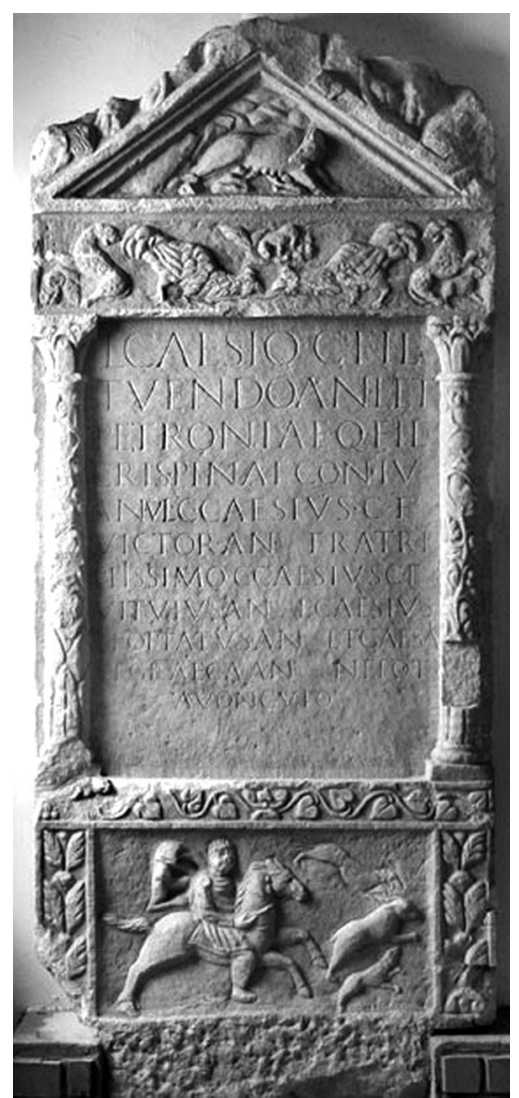

Fig. 20. (LEFT) Gravestone from Chernelházadamonya, Pannonia Superior (no. 16). 125-200 CE. Photo source: TótH 2011, 222

${ }^{146}$ Cf. Weigel 1977, 34; L. Cracco RugGini: L'opinione di uno storico. In: BARTOLONI 2010, 81-100; MAZZONI 2010, 193-204.

${ }^{147}$ A. Gannon: The Iconography of Early Anglo-Saxon Coinage. Sixth to Eighth Centuries. Oxford 2003, 144 - 147; GANNON 2007, 292-303.

${ }^{148}$ A. L. VANDERSALL: The date and provenance of the Franks casket. Gesta 11 (1972) 9-26; S. SETTIS: Memoria dell'antico

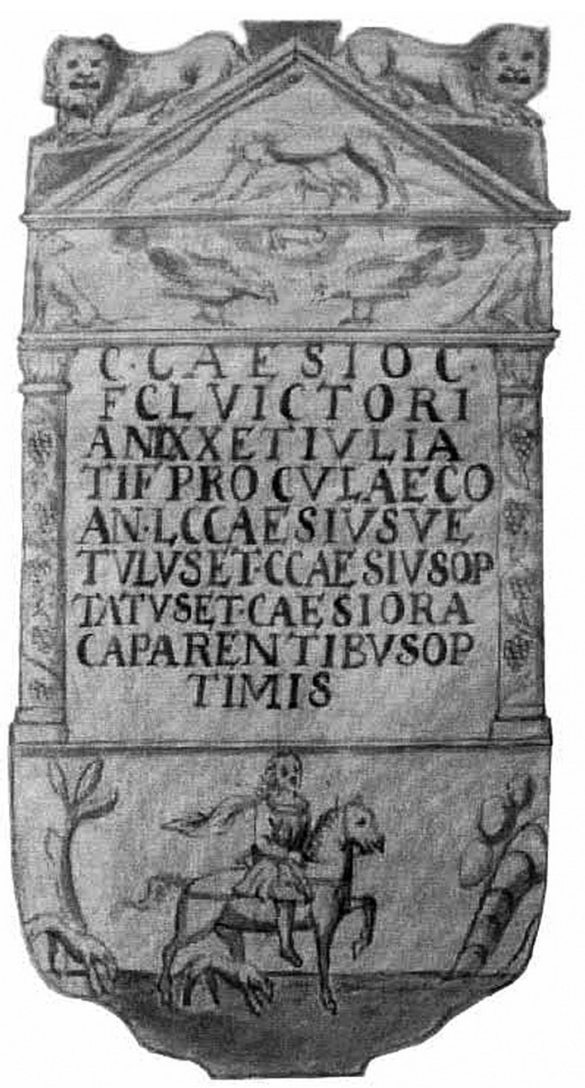

Fig. 21. (RIGHT) Gravestone from Répceszentgyörgy, Pannonia Superior (no. 17). 125-200 CE. Drawn by J. C. Iselin. Photo source: Tóth 2011, 220

nell'arte italiana. 3. Torino 1986, 437-445. There is a Runic inscription on the casket: oPlacunneg / Romwalus and Reumwalus / two gengibroðar a / foedda hicewylif / in Roma castri "Romulus and Remus, two brothers: a she-wolf fed them in Rome city, far from their native land"(translated by A. L. Vandersall). 

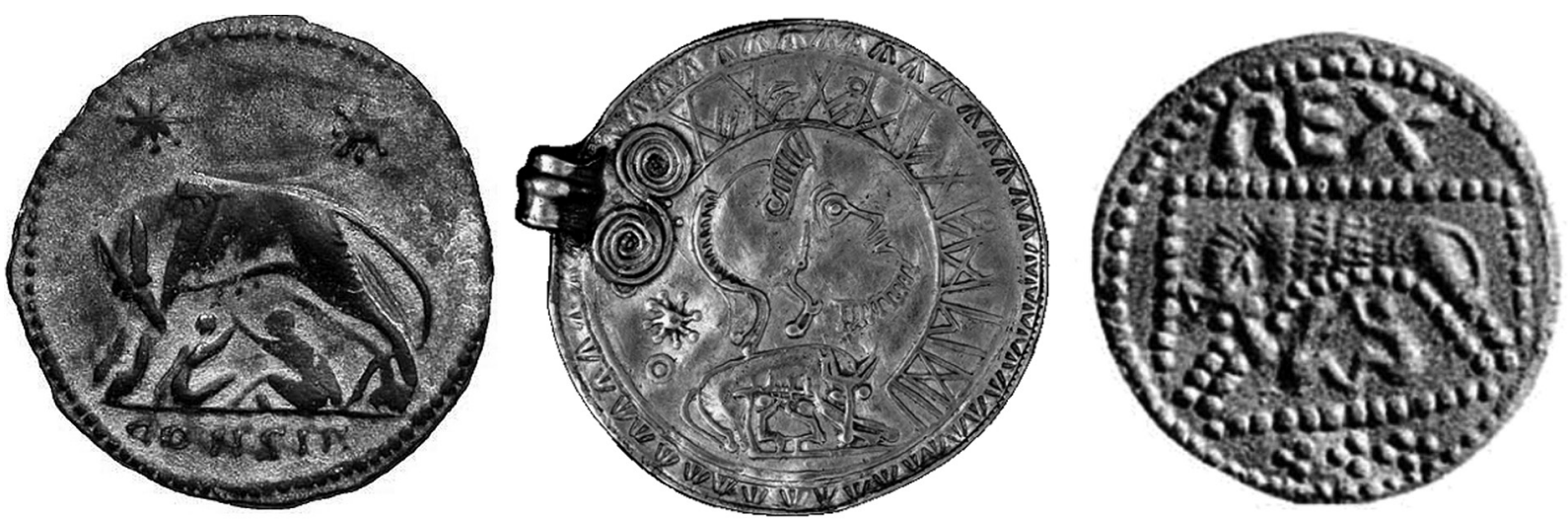

Fig. 22. Reproduction of the Constantinian pictorial motif in Anglo-Saxon art. A: (LEFT) Reverse of the Roman bronze follis: the she-wolf with the twins, two stars and the inscription Consia. 330-333 CE. Photo source: www.beastcoins.com;

B: (MIDDLE) Golden bracteate found in Undley, with the goddess Roma, depicted as a bearded male, the she-wolf and an uncertain Runic inscription. 420-450 CE. Photo source: British Museum;

C: (RIGHT) Reverse of the Anglo-Saxon penny of Æthelberht of East Anglia with the inscription rex. Late $8^{\text {th }}$ century. Photo source: GANNON 2007, Fig. 13.3

The legend of Romulus and Remus who were suckled by a wolf became widespread in Antiquity, and its pictorial representations were produced without any obvious connection with the idea of romanitas. For example, the above-mentioned image from Constantinian coins was depicted in Anglo-Saxon art as early as in the $5^{\text {th }}$ century Undley bracteate (Fig. 22.b), which was found in Britain but presumably originated in northern Germany or southern Scandinavia. The bracteate combined both the obverse image of the Constantinian coin, the goddess Roma, and the reverse image of the she-wolf. The reason why this pictorial motif was chosen for the bracteate is unknown. ${ }^{149}$

The she-wolf motif was also used on Persian seal-stones of the Sasanian Period ( $3^{\text {rd }}$ to $7^{\text {th }}$ century CE). The composition differs from the Roman archetype and shows a roughly drawn animal, usually with an erect neck. ${ }^{150} \mathrm{G}$. Azarpay believes that the seal-stone motifs did not have any pictorial model but were designed after the oral tradition of the legend of Romulus and Remus. Some references to a legend of human babies nursed by a wolf are known from Persian folk poetry, too. ${ }^{151}$ The motif of the she-wolf has been found as far east as Shahristan, Tajikistan, in a $7^{\text {th }}$ to $9^{\text {th }}$ century painting. Even though the image was obviously copied from Roman artwork, supposedly from Byzantine medallions and bracteates, ${ }^{152}$ the Roman origin and the original significance of the pictorial motif were probably quite unknown to the locals. A wolf suckling human infants (both in the case of the Sasanian seal-stones and the wall painting of Shahristan) was just a miracle with universal interest, without any association with the Roman Empire.

In modern Europe, however, the Roman heritage is still alive. In 1906 the municipality of Rome donated a bronze copy of the Lupa Capitolina to Bucharest. In the interwar period, six similar donations ${ }^{153}$ were made to other Romanian towns (both before and after Mussolini's rise to power). ${ }^{154}$ The function of the statues, Statuii

${ }^{149}$ J. HINES: The Scandinavian Character of Anglian England in the Pre-Viking Period. BAR British Ser. 124. Oxford 1984, 204-205.

${ }^{150}$ In some variants a wolf is suckling a human infant and a wolf cub together, an infant on its own, or a wolf cub only.

${ }^{151}$ G. AZARPAY: The Roman twins in the Near Eastern art. Iranica Antiqua 23 (1988) 349-360. Furthermore, the legend of Romulus and Remus might have had an influence on the Chinese and Mongol legends of Wu-sun and Kun-mo. Cf. E. G. Pulleybank: The Wu-sun and Sakas and the Yüeh-chih Migration. Bulletin of the School of Oriental and African Studies 1 (1970) 156; N. JILA: Myths and traditional beliefs about the wolf and the crow in Central Asia. Asian Folklore Studies 65 (2006) 171-174

152 AZARPAY 1988, 354; R. OTA: Imaginea lupei Capitolina în Asia Centrală. Apulum 42 (2005) 193-196.
${ }^{153}$ Cluj-Napoca and Chișinău (1921), Târgu Mureș (1924), Timișoara (1926), Alba Iulia (1933) and Satu Mare (1936).

${ }^{154}$ After World War II, the she-wolf statues were despised because of their association with fascist Italy. Some of them were removed or even destroyed. When the political climate changed, the statues reappeared in their positions of honor. For example, in 1968 when Nicolae Ceausescu challenged the authority of the Soviet Union, the she-wolf statue was replaced in Timișoara. The statue of Satu Mare disappeared in 1940, and a copy was re-erected in 1992. M. BĂRBULESCU: Lupa Capitolina. Tribuna 59 (2005) 34; G. MusCARDINI: Uomini e lupe. La lupa imperiosa e la affinità dacoromana. Belfagor 369 (2007) 321-329; G. MusCARDINI: La Lupa Capitolina e la continuità dacoromana. Dacia 52 (2008) 211-223. 
Lupoaicei, which are more or less exact copies of the Lupa Capitolina (unlike the she-wolf images of ancient Roman Dacia discussed above), can be seen somehow as parallels to the provincial she-wolf representations of Antiquity. The Lupoaicei were an indication of both the Roman origin of Romanian identity and of a political tie between Italy and Romania. ${ }^{155}$ Similarly, in the early 1900s the Roman origin of the city of Cologne was emphasized with the erection of a copy of the Lupa Capitolina at the top of Römerbrunnen, the Roman fountain. ${ }^{156}$

\section{CONCLUSIONS}

The she-wolf nursing Romulus and Remus was an iconic scene that was not used randomly in provincial art. It represented in the first place the idea of romanitas, being Roman, which could be based either on concrete links, such as an individual's citizenship or military career, or on a special occasion with which a town was linked to Rome, or on a person's self-identification as a Roman.

In Roman religion the wolf was traditionally associated with Mars. In provincial art, however, the wolf was more often connected with the state cult. Therefore it can be argued that the she-wolf did not have as deep a religious significance in the Roman provinces as it had in Italy; it was not regarded primarily as a religious symbol but as a symbol of the Roman Empire.

In some cases, such as on the coins of Aelia Capitolina and the cuirasses of Hadrian, the use of the symbol could have been in consequence of instructions from Rome itself or from provincial authorities that depended on Rome, but in most cases the motif was used by the inhabitants of the provinces themselves. It can be seen as an expression of loyalty to Rome and the emperor, but at the same time the message could have been directed to other members of the community, too. As romanitas was associated with higher social status, the she-wolf motif in the decoration of one's house or gravestone could be seen as self-aggrandizement. The symbol acquired different connotations in different contexts of use. For example, the idea of aeternitas, first promoted on Roman coinage, became associated with immortality, which possibly had its influence on the use of the she-wolf as a pictorial motif on gravestones.

As Figure 3 presented above shows, the findings of the different kinds of artwork in which the Lupa motif was used are not distributed evenly throughout the provinces: the coins and imperial breastplates are concentrated mainly in the east, the gravestones in the Danubian provinces, and most of the decoration on buildings in the western part of the Empire. The distribution of the Hadrianic breastplates can be explained by their being part of imperial propaganda and expressions of Hadrian's philhellenism. The minting of coins was probably controlled by the administration, and the license to use the motif of the Lupa on them was a privilege that was granted mostly to cities in the eastern part of the Empire. The concentration of gravestones in the Danubian provinces may be related to the low literacy rate of the provinces. The she-wolf was an unambiguous symbol of Rome, associated with a higher social status, and the local elite could use it in order to draw attention to their rank. In other cases, the geographical distribution can be explained by the location of the fortresses of the legions which had the she-wolf as their emblem, or simply as a coincidence, with no political or practical reasons behind it.

The multiple use of the she-wolf as the symbol of romanitas can also be seen from its aftermath. After the fall of the Roman Empire, the image of the Lupa Romana both retained its old significance as the symbol of Rome and developed some new connotations. It acted as a symbol of continuity between the Roman Empire and the rulers of the time, thus proclaiming their authority to rule. On the other hand, it was sometimes interpreted as the symbol of the Christian church, which was seen to have originated in Rome. The motif was also used without any knowledge of its origin, being just a depiction of a fabulous story of infants nursed by animals. In Antiquity, however, even though the she-wolf motif could have been used without any visual models, it was always recognized as the Lupa Romana, the symbol of Rome.

${ }^{155}$ After the fall of communism, nearly twenty new statues have been erected in Romania. They have mainly been financed by private persons.
${ }^{156}$ P. NoELKe-S. LiEb: Der Kölner Römerbrunnen von Franz Brantzky (1910-1915) und seine Neugestaltungdurch Karl Band (1954-1955). Wallraf-Richartz-Jahrbuch 53 (1992) 223-268. 


\section{REFERENCES}

AichHOLZER 1983

ALBERTSON 2012

AMISANO 2004

AZARPAY 1988

BARTOLONI 2010

BERGMANn 2010

BURGER 1964

BURNETT et al. 1992

CADARIO 2001

CARANDINI 2006

CARANDini-CAPELli 2000

CRAWFORD 1972

DARDENAY 2010a

DARDENAY 2010b

DARDENAY 2012

DELAMARRE 2007

DITSCH 2011

DULIÈRE 1979

ERDÉLYI 1950

EVANS 1992

GANNON 2007

GERGEL 2004

GIUNIO 2005

HowgEgo et al. 2005

KEMPCHEN 1995

KÜNZL 1996

MERCANDO - PACI 1998

Mócsy 1974

PARISI PRESICCE 2000

PICARD 1987

POP 1971

SCHAUENBURG 1966

SCHOBER 1923
= P. AICHHOlzER: Darstellungen römischer Sagen. Universität Wien [Diss.] 1983.

= F. C. Albertson: Mars and Rhea Silvia in Roman Art. Collection Latomus 336. Bruxelles 2012.

= G. AmisAno: La storia di Roma antica e le sue monete. I: Dalle origini alla supremazia in Italia. Cassino 2004

= G. AzARPAY: The Roman twins in the Near Eastern art. Iranica Antiqua 23 (1988) 349-360.

= G. BARTOLOni (ed.): La Lupa Capitolina. Nuove prospettive di studio. Roma 2010.

$=$ B. Bergmann: Bar Kochba und das Panhellenion. Die Panzerstatue Hadrians aus Hierapytna/Kreta (Istanbul, Archäologisches Museum Inv. Nr. 50) und der Panzertorso Inv. Nr. 8097 im Piräusmuseum von Athen. IstMitt 60 (2010) 234-235; 258-288.

= A. Sz. Burger: Die Szene der „lupa Capitolina” auf provinzialen Grabsteinen. FolArch 13 (1964) $51-55$.

= A. Burnett-M. Amandry-P. Pau Ripollès: Roman Provincial Coinage. 1. London 1992.

= M. CADARIO: 'Primor diaurbis Romae' in Piemonte. Lupa Romana e fuga di Eneane i monumenti funerari. In: G. Sena Chiesa (ed.): Il modello Romano in Cisalpina. Milano 2001, 151-160.

= A. CARAndini (ed.): La leggenda di Roma. I: Dalla nascita dei gemelli alla fondazione della Città. Roma 2006

= A. CARANDini-R. CAPElli (eds): Roma. Romolo, Remo e la fondazione della città. (Catalogo della mostra.) Roma, Museo Nazionale Romano. Terme di Diocleziano. 28 giugno-29 ottobre 2000. Roma-Milano 2000

= M. CRAWFORD: Roman Republican Coinage. Cambridge 1972.

= A. DARDENAY: Les mythes fondateurs de Rome: images et politique dans l'Occident romain. Paris 2010.

= A. DARDENAY: La diffusion iconographique des mythes fondateurs de Rome dans l'Occident romain : spécificités hispaniques. In: A. Caballos Rufino-S. Lefebvre (eds.): Roma generadora de identidades. La experiencia hispana. Madrid 2010, 79-96.

= A. Dardenay: Images des fondateurs. D'Enée à Romulus. Coll. scripta Antiqua 43. Bordeaux 2012.

$=$ X. Delamarre: Nomina Celtica Antiqua Selecta Inscriptionum (Noms de personnes celtiques dans l'épigraphie classique). Paris 2007.

$=$ S. Ditsch: Dis Manibus. Die Römischen Grabdenkmäler aus der Pfalz. Neustadt an der Weinstrasse 2011.

= C. Dulière: Lupa Romana. Recherches d'Iconographie et Essai d'Interprétation. Études de philologie, d'archéologie et d'histoire anciennes publiées par l'Institut historique belge de Rome 18 . Rome 1979.

= G. ERDÉLYI: Pannóniai római sírtáblák mitológiai jelenetekkel (Stèles romains pannoniens ornés de scénes mythologiques). ArchÉrt 77 (1950) 72-82.

$=$ J. Evans: The Art of Persuasion, Political Propaganda from Aeneas to Brutus. Ann Arbor 1992

= A. Gannon: Three coins in a fountain. In: É. Ó. Carragáin - C. Neuman de Vegvar (eds): Roma Felix - Formation and Reflections of Medieval Rome. Ashgate 2007, 292-303.

$=$ R. A. GERGEL: Agora S166 and related works: The iconography, typology, and interpretation of the eastern Hadrianic breastplate type. In: A. P. Chapin (ed.): Xa@ıs. Essays in Honor of Sara A. Immenwahr. Hesperia Supplement 33. Athens 2004, 371-410.

= K. A. GIUNIO: Religion and myth on monuments from Zadar and surroundings in the Archeological Museum in Zadar. In: M. Sanader-A. Rendić-Miočević (red.): Akti VIII. međunarodnog kolokvija o problemi marimskog provincijalnog stvaralaštva. Zagreb 2005, 213-222.

= C. Howgego-V. Heuchert-A. Burnett (eds): Coinage and Identity in the Roman Provinces. Oxford 2005 .

= M. KEMPCHEN: Mythologische Themen in der Grabskulptur: Germania Inferior, Germania Superior, Gallia Belgica und Raetia. Charybdis 10. Münster 1995.

= E. KüNZL: Gladiusdekorationen der frühen römischen Kaiserzeit: dynastische Legitimation, Victoria und Aurea Aetas. JRGZM 43 (1996) 406-411.

= L. MerCANDO-G. PACI: Stele romane in Piemonte. Roma 1998

= A. Mócsy: Pannonia and Upper Moesia. A History of the Middle Danube. Provinces of the Roman Empire. London 1974.

= C. PARISI Presicce (ed.): La Lupa Capitolina. Roma 2000.

= C.-G. PICARD: La Louve romaine, du mythe au symbole. RA 1987, 257-263.

= C. PoP: Reprezentări cu lupa Capitolina pe monumente romane din România. Acta Musei Napocensis 8 (1971) 173-185.

= K. Schauenburg: Die Lupa Romana als sepulkrales Motiv. JDAI 81 (1966) 261-309.

= A. Schober: Die römischen Grabsteine von Noricum und Pannonien. Wien 1923. 
SNG

SZIRMAI 1989

TóTH 2011

WEIGEL 1977

WeIGEL 1992
$=$ H. vON AUlOCK - G. KLEINER (Hrsg.): Sylloge nummorum Graecorum. Deutschland. Sammlung v. Aulock. Berlin 1957-1968.

= K. SZIRMAI: Die Lupa Capitolina - Darstellungen auf den pannonischen Steindenkmäler. MAGS 3-4 (1989-90) 162-167.

= Е. То́тн: Lapidarium Savariense. Szombathely 2011.

= R. D.WeIgEL: The lupa Romana theme on Roman coins. Society for Ancient Numismatics Journal 8 (1977) 25-26.

= R. WeIGEL: Lupa Romana. In: LIMC VI. Zürich 1992, 292-296. 